\title{
EL DESPLAZAMIENTO FORZADO EN COLOMBIA: 10 AÑOS DE LA SENTENCIA T-025 DE 2004
}

María Lucía Torres Villarreal

Paola Marcela Iregui Parra

-Editoras académicas-

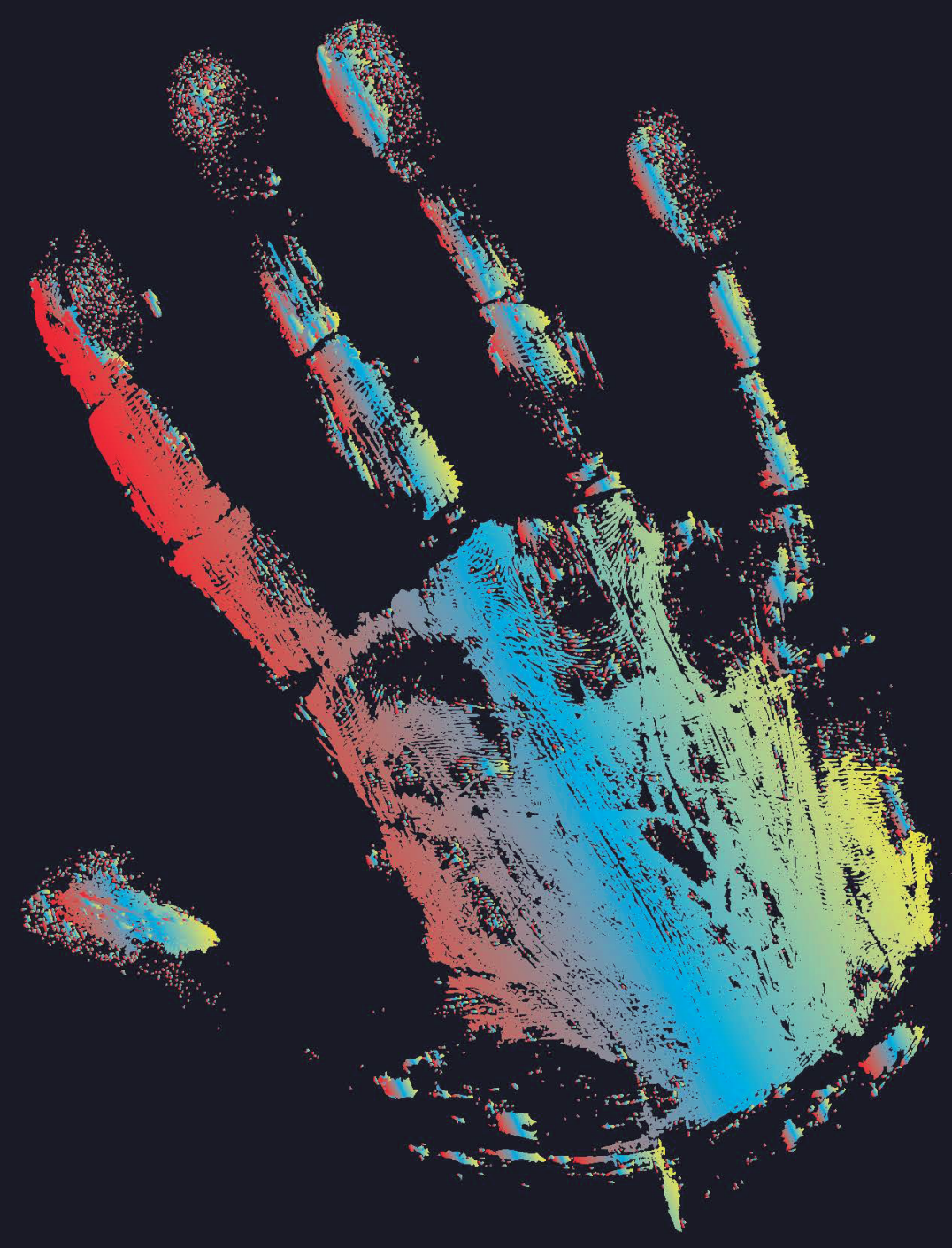

\section{Fundación \\ Hanns Seidel}

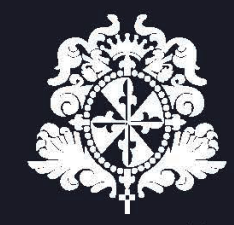

UNIVERSIDAD DEL ROSARIO 

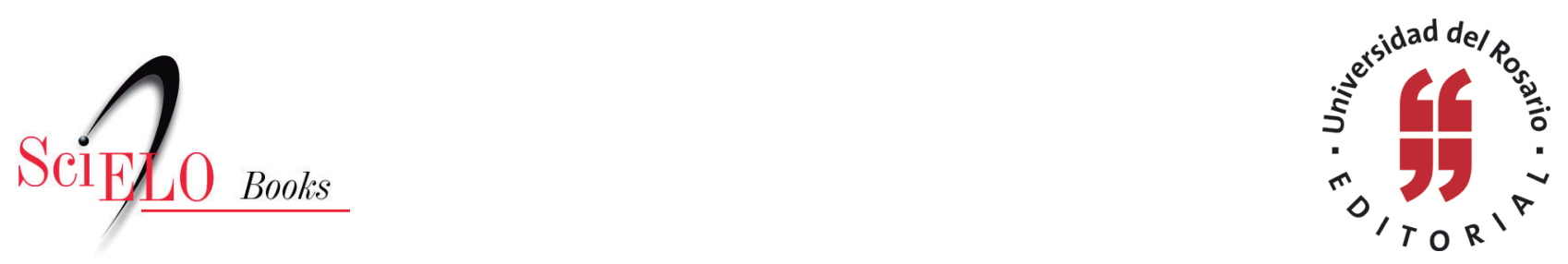

\title{
El desplazamiento forzado en Colombia 10 años de la Sentencia T-025 de 2004
}

\author{
María Lucía Torres Villarreal \\ Paola Marcela Iregui Parra \\ (Editoras académicas)
}

\section{SciELO Books / SciELO Livros / SciELO Libros}

TORRES VILLARREAL, M.L., and IREGUI PARRA, P.M., eds. El desplazamiento forzado en Colombia: 10 años de la sentencia T-025 de 2004: ponencias ganadoras del IV Concurso Nacional de Semilleros de Investigación [online]. Bogotá: Editorial Universidad del Rosario, 2015, 91 p. Textos de Jurisprudencia collection, Semilleros series. ISBN: 978-958-738-559-5. https://doi.org/10.7476/9789587385595.

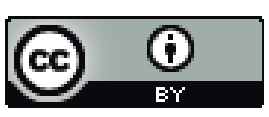

All the contents of this work, except where otherwise noted, is licensed under a Creative Commons Attribution 4.0 International license.

Todo o conteúdo deste trabalho, exceto quando houver ressalva, é publicado sob a licença Creative Commons Atribição 4.0.

Todo el contenido de esta obra, excepto donde se indique lo contrario, está bajo licencia de la licencia $\underline{\text { Creative }}$ Commons Reconocimento 4.0. 
Fundación Hanns Seidel

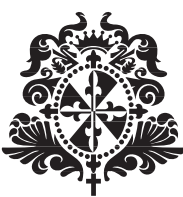

UR 



\section{El desplazamiento forzado en Colombia: 10 años de la Sentencia T-025 de 2004}


El desplazamiento forzado en Colombia: 10 años de la sentencia T-025 de 2004: ponencias ganadoras del IV Concurso Nacional de Semilleros de Investigación / editoras académicas María Lucía Torres Villarreal, Paola Marcela Iregui Parra.—Bogotá: Editorial Universidad del Rosario, Facultad de Jurisprudencia, 2015.

xiii, 91 páginas. - (Colección Textos de Jurisprudencia, Serie Semilleros)

ISBN: 978-958-738-558-8 (rústica)

ISBN: 978-958-738-559-5 (digital)

Conflicto armado - Colombia / Colombia - Política y gobierno / Paz / Violencia / Ejército Nacional de Colombia / Reparación (Derecho penal) / Justicia transicional / Derechos humanos / I. Título / II. Serie.

303.6 SCDD 20

Catalogación en la fuente - Universidad del Rosario. Biblioteca amv 


\title{
E1 desplazamiento forzado en Colombia: 10 años de la Sentencia T-025 de 2004
}

\author{
María Lucía Torres Villarreal \\ Paola Marcela Iregui Parra \\ -Editoras académicas-
}




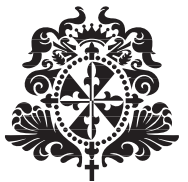

Colección Textos de Jurisprudencia Serie Semilleros

(C) 2015 Editorial Universidad del Rosario

(C) 2015 Universidad del Rosario, Facultad de Jurisprudencia

(C) 2015 Fundación Hanns Seidel

(C) 2015 María Lucía Torres Villarreal, Paola Marcela Iregui Parra

Editorial Universidad del Rosario

Carrera 7 No. 12B-41, of. 501

Tel: 2970200

http://editorial.urosario.edu.co

\section{Fundación}

Hanns Seidel
Primera edición: Bogotá D. C. enero de 2015

ISBN: 978-958-738-558-8 (rústica) ISBN: 978-958-738-559-5 (digital)

Coordinación editorial:

Editorial Universidad del Rosario

Corrección de estilo: Claudia Ríos

Diseño de cubierta y diagramación:

Precolombi EU-David Reyes

Impresión: Estrategikmente Ltda.

Impreso y hecho en Colombia

Printed and made in Colombia

Fecha de evaluación: 24 de septiembre de 2014

Fecha de aceptación: 03 de noviembre de 2014

Todos los derechos reservados. Esta obra no puede ser reproducida sin el permiso previo escrito de la Editorial Universidad del Rosario 


\section{Contenido}

Presentación.................................................................... ix

María Lucia Torres Villareal y

Paola Marcela Iregui Parra

Ponencia ganadora Primer puesto: Cumplimiento de las condenas contra Colombia por desplazamiento forzado interno en el Sistema Interamericano................

Johana Alvarez Rincón y

Gabriel Alejandro Quintero Sánchez

Universidad Católica de Colombia

Ponencia ganadora Segundo puesto: La discusión probatoria de las víctimas y la Sentencia T-025 de 2004.

Maria Alejandra Lozano,

Ana Sofía Payán y

Luis Enrique Ruiz

Grupo de Acciones Públicas, Universidad del Rosario

Ponencia ganadora tercer puesto:

La justicia transicional de la Ley 1448 de 2011

¿beneficio o impunidad?

61

Diana Judith Arenas Jiménez,

Gustavo Adolfo Basto Forero,

Nathalia Andrea Marín Hernández y

Lina Maria Mejia Torres

Universidad Santo Tomás, Sede Villavicencio 



\section{Presentación}

Al igual que en los tres años anteriores, la Universidad del Rosario, por conducto del Observatorio Legislativo y el Grupo de Investigación en Derechos Humanos de la Facultad de Jurisprudencia, se ha asociado con la Fundación Hanns Seidel para organizar el Concurso Nacional de Semilleros de Investigación, el cual tiene por objeto promover e incentivar entre los estudiantes de diferentes áreas del conocimiento, la investigación enfocada hacia temáticas de especial relevancia para el país, lo cual representa un aporte que, desde la etapa de formación, los futuros profesionales de nuestra nación hacen para el análisis y la reflexión de esos temas.

Entendiendo la importancia de que las nuevas generaciones de profesionales se comprometan y construyan una visión propia y estructurada de esos temas, la cuarta versión del concurso buscó hacer una reflexión, desde diversas perspectivas, alrededor del desplazamiento forzado en Colombia y las medidas que se han adoptado desde la declaratoria del estado de cosas inconstitucional de la Sentencia T-025 de 2004, proferida por la Corte Constitucional.

Como es sabido, la sentencia mencionada evaluó el estado del fenómeno del desplazamiento forzado y condujo a declarar el estado de cosas inconstitucional, en razón del reconocimiento a la delicada situación de derechos humanos 
de la población desplazada. En dicho fallo, la Corte estableció una serie de órdenes que debían ser cumplidas por diferentes instituciones, con el fin de conjurar la crisis y sentar las bases para poner fin a las graves amenazas y violaciones de derechos humanos que estaban sucediendo respecto de la población afectada por el desplazamiento forzado, producto del conflicto armado interno. Para hacer seguimiento a estas órdenes, se creó, dentro de la Corte Constitucional, la Sala de Seguimiento a la Sentencia T-025, la cual ha venido vigilando el cumplimiento del fallo, a través de la expedición de más de 90 autos.

La coyuntura actual del país, la existencia de una mesa de negociaciones y el posible ingreso a un periodo de transición, sumado a los diez años de haberse proferido el fallo nos invitan a dirigir nuestra mirada sobre los más de cinco millones ${ }^{1} \mathrm{de}$ desplazados que existen hoy en Colombia y con ello evaluar los aportes que desde el Estado, las organizaciones y la academia se brindan para dar soluciones constructivas a la incierta situación de derechos que vive esta población.

Precisamente, para lograr un estudio más a fondo de las temáticas que se abordan en nuestro concurso, siempre se planea la competencia en el marco de un seminario internacional que evoque el mismo tema. Para este año, se organizó el foro "El Desplazamiento Forzado en Colombia: Diez años de la Sentencia T-025 de 2004", en el que, desde una perspectiva internacional, nacional y académica, se buscó establecer cuál es el estado actual del desplazamiento en Colombia y qué ha pasado con las órdenes impartidas por la Corte Constitucional. Fundamentalmente, el objetivo fue reconocer los cambios

1 Sistema de Información sobre Derechos Humanos y Desplazamiento SISDHES. 
que han existido en la situación de hecho y de derecho de la población desplazada y cuáles son las nuevas dinámicas que han surgido alrededor de esta problemática y que de seguro no existían cuando la Corte profirió tan importante sentencia.

Con el fin de analizar el estado del desplazamiento forzado en Colombia, al ser una problemática recurrente en nuestro país desde hace varios años, las ponencias recibidas dentro de la convocatoria para el IV Concurso de Semilleros de Investigación, por parte de las diferentes instituciones educativas del país, abordaron este importante tema. De todas las ponencias presentadas, fueron seleccionadas doce para participar en la fase oral que se dio cita los días 5 y 6 de agosto de 2014, en la Universidad del Rosario. Tanto la fase oral cuanto la escrita contaron con la participación de profesores de altas calidades profesionales y académicas que en calidad de pares evaluadores y jurados, en una y otra fase, certificaron la calidad de las ponencias presentadas y con ello los resultados obtenidos.

Este texto contiene las ponencias de los estudiantes ganadores del concurso, pues el objetivo es publicar los mejores escritos del certamen, a manera de premio y de esa forma, seguir enriqueciendo el debate académico con la investigación realizada por parte de los estudiantes en temas de actualidad jurídica, política y social. Con el ejercicio pedagógico de este concurso, se observaron los resultados y la importancia de la investigación formativa en las facultades de derecho y todas las carreras afines, siendo el presente libro una prueba de ello.

Así, esta obra se constituye en la cuarta publicación de ponencias ganadoras del concurso, bajo el sello de la Editorial de la Universidad del Rosario y gracias a la financiación de la Fundación Hanns Seidel, que desde un principio creyó y respaldó esta iniciativa. Así, continuamos con nuestro deber como academia de incentivar el debate académico a partir 
de la investigación realizada por parte de los estudiantes y cumplimos con nuestro objetivo de seguir construyendo la Colección Semilleros de Investigación que la Universidad del Rosario ha diseñado para estos fines y que es distribuida a las diferentes bibliotecas nacionales, departamentales y universitarias, buscando llegar al mayor número de destinatarios posibles para que puedan compartir las reflexiones que hacen nuestros estudiantes, lo cual coincide con los objetivos misionales de la Fundación Hanns Seidel.

En el presente texto, se publican las ponencias de los estudiantes que ocuparon los tres primeros puestos dentro del IV Concurso Nacional de Semilleros de Investigación, evidenciando con ello un importante esfuerzo en el proceso de investigación formativa que cada vez interesa a más estudiantes de diferentes áreas del conocimiento y de diversas regiones de nuestro país. Los resultados fueron:

1. Primer Puesto: "Cumplimiento de las condenas contra Colombia por desplazamiento forzado interno en el Sistema Interamericano" Autor: Johana Álvarez Rincón y Gabriel Alejandro Quintero Sánchez

Universidad Católica de Colombia, Bogotá

2. Segundo Puesto: "La discusión probatoria de las víctimas y la Sentencia T-025 de 2004"

Autores: María Alejandra Lozano, Ana Sofía Payán y Luis Enrique Ruiz.

Grupo de Acciones Públicas, Universidad del Rosario, Bogotá

3. Tercer Puesto: "Justicia transicional de la Ley 1448 de 2011 ¿beneficio o impunidad? 


\begin{abstract}
Autor: Diana Judith Arenas Jiménez, Gustavo Adolfo Basto Forero, Nathalia Andrea Marín Hernández y Lina María Mejía Torres.

Universidad Santo Tomás, sede Villavicencio
\end{abstract}

Queremos felicitar a los estudiantes ganadores de la competencia por su impecable trabajo y los invitamos a seguir participando en este tipo de iniciativas que fortalecen su formación y les permite adquirir habilidades para el ejercicio de su profesión, en el área del conocimiento en la cual se desempeñen. Reiteramos nuestro agradecimiento por la participación y los invitamos para que nos acompañen en la $\mathrm{v}$ versión del concurso que se realizará el próximo año. De igual forma, agradecemos a la Fundación Hanns Seidel su invaluable colaboración y el apoyo que se ha dado a este proyecto que conlleva el fortalecimiento de la democracia y sus pilares, desde la formación de nuestros futuros profesionales.

María Lucía Torres Villarreal

Profesora de carrera académica

Facultad de Jurisprudencia
Paola Marcela Iregui Parra

Profesora de carrera académica

Facultad de Jurisprudencia 



\title{
Cumplimiento de las condenas contra Colombia por desplazamiento forzado interno en el Sistema Interamericano*
}

\author{
Johana Álvarez Rincón*" \\ Gabriel Alejandro Quintero Sánchez
}

* Ponencia desarrollada en el proyecto de investigación actualmente en ejecución "Cumplimiento de las sentencias de la Corte Interamericana de Derechos Humanos: Revisión del caso Colombiano en Perspectiva Comparada”, realizada conjuntamente por Johana Álvarez Rincón, auxiliar de Investigación, y Gabriel Alejandro Quintero Sánchez, miembros del Semillero de Investigación Observatorio en Justicia Constitucional y Derechos Humanos, y bajo la dirección de la líder de Investigación, la profesora Tania Giovanna Vivas Barrera, vinculados todos al Grupo de Investigaciones "Personas, Instituciones y Exigencias de Justicia”, adscrito al Centro de Investigaciones Sociojurídicas cisjuc de la Facultad de Derecho de la Universidad Católica de Colombia.

** Estudiante de noveno semestre de Derecho de la Universidad Católica de Colombia. Auxiliar de Investigación y miembro del Semillero de Investigación Observatorio en Justicia Constitucional y Derechos Humanos del Grupo de Investigaciones "Personas, Instituciones y Exigencias de Justicia”, adscrito al Centro de Investigaciones Sociojurídicas cisjuc de la Facultad de Derecho de la Universidad Católica de Colombia. Correo electrónico: ajalvarez09@ucatolica.edu.co

*** Estudiante de séptimo semestre de Derecho de la Universidad Católica de Colombia. Auxiliar de Investigación y miembro del Semillero de Investigación Observatorio en Justicia Constitucional y Derechos Humanos del Grupo de Investigaciones "Personas, Instituciones y Exigencias de Justicia", adscrito al Centro de Investigaciones Sociojurídicas cisjuc de la Facultad de Derecho de la Universidad Católica de Colombia. Correo electrónico: gaquintero89@ucatolica.edu.co 


\section{Resumen}

La población colombiana ha sido históricamente víctima de desplazamiento forzado interno, flagelo calificado hoy en día como delito de lesa humanidad. Los niveles de desplazamiento forzado ubican a Colombia encabezando los listados de las principales organizaciones en llevar a cabo el monitoreo de las estadísticas de desplazamiento forzado, de países con mayor índice de violaciones, de allí la importancia de vigilar el comportamiento del país. Por ello, partimos de considerar en un primer momento la información hoy disponible sobre la extensión geográfica de la violación, las causas y factores que influyen en los altos niveles y las circunstancias políticas, sociales y económicas que trae como consecuencia la presencia de este fenómeno. Concebimos además como asunto primordial tener en cuenta los niveles de cumplimiento de las sanciones impuestas por el Sistema Interamericano en las sentencias que han condenado la violación del derecho a la libre circulación consagrado en la Convención Americana de Derechos Humanos.

\section{Palabras clave}

Corte Interamericana de Derechos Humanos, desplazamiento forzado, cumplimiento, sentencias.

\section{Introducción}

El estudio del presente caso tiene dos focos de análisis de la situación colombiana. La primera parte de la investigación tiene como base estructural el establecimiento de lo que consideramos como desplazamiento interno, además se concentrará en la posición internacional que ha ganado el país dentro de las estadísticas mundiales y continentales sobre este fenómeno. La segunda parte de la investigación está encaminada a analizar todas las condenas contra el Estado colombiano emanadas de 
la Corte Interamericana de Derechos Humanos y los niveles de cumplimiento de las órdenes recogidas en las sentencias.

\section{Metodología}

El método investigativo empleado en la presente ponencia es un método mixto, entre una descripción de la realidad objeto de estudio, el análisis de cifras, la situación de desplazamiento forzado a nivel mundial respecto del caso colombiano, la comparación en relación a los índices sobre el desplazamiento en diferentes países también en conflicto y un análisis de caso desde la perspectiva del Sistema Interamericano de Derechos Humanos y los casos contenciosos contra Colombia en lo relacionado con víctimas de desplazamiento forzado y la responsabilidad del Estado frente a las consecuencias que esta puede generar. Así, se podrá entonces inferir cuál es el nivel de cumplimiento de las órdenes dictadas por la Corte Interamericana de Derechos Humanos y cuáles son las garantías para las personas víctimas de este fenómeno.

\section{Primera parte. Colombia en las estadísticas internacionales sobre desplazamiento forzado interno}

\section{¿Qué se entiende por desplazado?}

Según la Oficina para la Coordinación de Asuntos Humanitarios de las Naciones Unidas (en adelante, OCAH) por desplazado ha de entenderse: "de acuerdo con los principios rectores de desplazamiento interno, los desplazados internos" $[\text { DI, en adelante }]^{1}$ son

\footnotetext{
1 IDPs. Internal Displacement Person, traducido al español, IDP, Personas Desplazadas Internas.
} 
[...] personas o grupos de personas que han sido forzadas u obligadas a escapar o huir de su hogar o lugar habitual de residencia, en particular como resultado o para evitar los efectos de un conflicto armado, situaciones de violencia generalizada, violaciones de derechos humanos o de catástrofes naturales o hechos realizados por el hombre, y que no han cruzado una frontera estatal internacionalmente reconocida (Principios Rectores de los Desplazamientos Internos, Art. 2).

El conflicto armado colombiano ha representado en América Latina una violencia abismal, ello se demuestra en la cantidad de personas que a la actualidad son víctimas del conflicto armado interno y debido a circunstancias de hecho han tenido que desplazarse de lo que conocen como sus hogares.

\section{Panorama internacional}

El estudio y análisis internacional de estadísticas de desplazamiento interno ha sido realizado por diferentes organizaciones, La principal organización internacional que ha llevado el seguimiento de las cifras y estadísticas ${ }^{2}$ internacionales es el Observatorio de Desplazados Interno (IDMc, en adelante). ${ }^{3}$

2 El IDMc realiza una búsqueda y recopilación de información de distintas fuentes, tal como son los gobiernos nacionales, de las Naciones Unidas, de organizaciones nacionales e internacionales no gubernamentales (ONG), organizaciones de derechos humanos, los medios de comunicación. Además que esta organización lleva a cabo misiones sobre el terreno a un número de países cada año para corroborar información o para encontrar nuevas estadísticas que aún no se han encontrado.

3 El Observatorio de Desplazados Internos (IDMC) es líder mundial en el seguimiento y análisis de las causas, efectos y respuestas a la cuestión de los desplazados internos, hace parte del Consejo Noruego para los Refugiados (NRC), organización no gubernamental internacional, independiente, humanitaria, sin ánimo de lucro, establecida en 1964. 
El problema social pertinente al desplazamiento tiene una connotación a nivel mundial, debido a que se presenta en los diferentes continentes del mundo. El IDMc elabora su estudio en las siguientes locaciones geográficas: América, África Subsahariana, en el Sur y Sudeste de Asia, en Medio Oriente, África del Norte, la zona del Cáucaso en Europa ${ }^{4}$ y Asia Central.

El continente africano es el continente que alberga la mayor cantidad de desplazados alrededor del mundo con 10,4 millones de desplazados internos, comprendiendo casi un tercio del total mundial. En el África Subsahariana los países que presentan mayores índices de personas desplazadas según los últimos estudios del IDMC son República Democrática del Congo con 2’634.872, Sudán con 2`426700, Somalia con 1'100.000 y Sudán del Sur con 956.200 DI, los cuales son los casos más dramáticos. Los menos dramáticos son Eritrea con 10.000, Liberia con 23.000, Togo con 1.500 y Níger con 11.000 Di. Cabe resaltar que hay países en los cuales no se tienen estudios recientes y ello dificulta establecer cifras actualizadas de este fenómeno; otros se encuentra en la posición en la cual ha podido establecerse una cifra como tal, como se presenta en el caso de Nigeria y Zimbawe. En el África del Norte, Argelia tiene cifras indeterminadas y Argelia contempla una cifra aproximada de 59.000 Di. La mayoría de los países en el continente africano ostenta una cifra entre 20.000 y 500.000 DI (IDMC, 2013).

La situación en el Medio Oriente y en el sudeste de Asia se ha propagado a países como Iraq que sostiene una cifra de 2`100.000, Siria con 6`500.000 y Pakistán con 747.000 DI.

$4 \quad$ Es una región situada entre Europa del Este y Asia Occidental, entre el Mar Negro y el Mar Caspio. 
El contexto americano se ve reflejado por países como México, Honduras, Perú y Colombia, este último ocupaba en 2013 el primer puesto con el mayor número de desplazados internos del mundo con un entre 4'900.000 y 5'500.000, cifra que al día de hoy se mantiene según un último informe del IDMC (IDMC, 2013).

Para el caso de Colombia, la situación es alarmante debido a que en el presente somos el segundo país con mayor cantidad de desplazados internos como consecuencia del conflicto armado y la violencia generalizada y sostenemos el primer puesto de desplazados internos en el continente americano según el IDMc. Esto lleva a realizarse una serie de preguntas: ¿cuáles son las circunstancias del conflicto que han conducido al país a ser de los principales países con mayor número de desplazados internos?, ¿qué políticas y normatividad se han hecho para buscar una solución al desplazamiento interno? lo que conlleva a desarrollar la índole de la problemática social en Colombia y por ende a establecer cuáles son los factores que determinan el conflicto.

\section{¿Cuáles son los factores que determinan el desplazamiento en Colombia?}

El conflicto armado interno que se presenta en Colombia ha tenido distintas dimensiones sociales, económicas y culturales, presentándose así, como consecuencia de ello, una violación de los derechos humanos permanentemente.

Aquellos factores que determinaron el éxodo de la población civil se deben a la estrategia de expansión territorial de los grupos paramilitares, las deficiencias en los procesos de desmovilización (Ley 975 de 2005), el reagrupamiento y rearme de algunos hombres de desmovilizados, la ofensiva militar de recuperación territorial del Estado en cumplimiento 
de la política de seguridad democrática, la siembra masiva e indiscriminada de minas antipersonales por parte de las FARC (Análisis extraídos del Centro Nacional de Memoria Histórica-CNMH-, 2013, p. 71).

Del progreso de los factores señalados se desembocan algunas consecuencias desarrolladas con el transcurso de los años, tales como son los rezagos propiciados por el narcotráfico, los intereses provenientes de sectores empresariales y la consecuencia ambiental proveniente del mal manejo de las tierras por parte de grupos al margen de la ley, de empresas y de la minería tanto legal como ilegal. ${ }^{5}$

\section{Margen del desplazamiento histórico en Colombia}

Existen diversas organizaciones gubernamentales y no gubernamentales que se han encargado de llevar la tarea de la recopilación de información para plasmarla en diferentes estadísticas. El Registro Único de Víctimas (en adelante, RUV) de la Unidad para la Atención y Reparación Integral de Víctimas y la Consultoría para los Derechos Humanos y el Desplazamiento (codHes, en adelante) han llevado el proceso para determinar las cifras pertinentes.

El proceso para determinar las cifras ha tenido distintas divergencias y diferentes problemáticas, dado que las cifras que emite el Ruv, el codHes y distintas organizaciones no

5 En este punto cabe resaltar el estudio de Oscar A. Alfonso (2011) en el cual señala que una de las circunstancias de agravación del desplazamiento se desprende del conflicto y la connotación ambiental que desarrollan algunos terrenos en el país, expresa : "en primer lugar, que la tierra de mejor calidad se encuentra controlada por poderes que no le es factible enfrentar o quienes sostienen vínculos indisolubles y, en segundo lugar, que muy probablemente esa tierra haya entrado en una fase de degradación que afecte su fertilidad por la extralimitación de su explotación, la mecanización, y el uso indiscriminado de fertilizantes que agotó el humus”. 
coinciden entre sí, pero las diversas fuentes de información sí convergen en que el desplazamiento forzado es una modalidad de violencia que ha tenido su incremento o escalada a partir del año 1996.

El reconocimiento por parte del Estado ha sido uno de los puntos que han retrasado el conflicto, ello se evidencia en que hasta el año 1997 el gobierno nacional emitió la Ley 387, con la cual se dio inicio a un registro oficial de datos (CNMH, 2013, p. 71), y estuvo parcialmente reglamentada hasta el año 2000 con el Decreto 2569.

La gravedad e incidencia del conflicto han tenido también consecuencias económicas y políticas, al punto de que en el vivir diario de la agenda pública este sea uno de los puntos importantes. Siguiendo el estudio de Brenda Pérez, a partir de la Ley 387 se comenzó a analizar la gravedad del desplazamiento con lo cual desde el año 1997 se crearon organizaciones e instituciones de gran importancia para la observación del conflicto "como el Sistema Nacional de Atención Integral a la Población Desplazada por la Violencia, el Plan Nacional para la Atención Integral a la Población Desplazada por la Violencia y el Programa Nacional de Atención Integral a la Población Desplazada por la violencia”(Pérez, 2014, p. 10).

La discrepancia de las cifras se logra evidenciar por la diferencia perceptible en la cantidad de desplazados internos, esta es presentada por las distintas fuentes y las diferentes metodologías empleadas para realizar los estudios de manera diversa: el RUV reportó 4'774.046 desplazados internos y el codHes estima 5'700.000 desplazados internos, del cual estima que para el periodo de 1985-1995 hubo un total de 819.510 víctimas de este delito de lesa humanidad. Se hace énfasis en el periodo 1985-1995 ya que el coDHes se creó en 1992 y sus trabajos comenzaron a emplearse a partir de 1995, 
que para sus análisis implementa el "Sistema de Información sobre Desplazamiento Forzado y derechos Humanos sidHes ${ }^{6}$ (Piñeros, 2012, p. 173)

Tal vez el caso más representativo del problema para diferenciar las cifras es el hecho que se presenta al decir que tres de cada diez hogares no reciben ayuda del Estado dado que no se encuentran registrados o están tramitando dicho registro (Piñeros, 2012, p. 10). El registro que mantiene el RUV no tiene cobertura general y universal del total de las víctimas del conflicto, lo que como consecuencia lleva a que se evidencie la falta de cubrimiento en que incurre el gobierno para resolver este fenómeno social. Desde 1997 se han emprendido esfuerzos para encontrar una solución frente a esta problemática, pero, siguiendo a la Corte Constitucional en Sentencia T025/04 (M.P.: M. J. Cepeda), la falta de acción ha constituido un problema grave dado que el registro de las víctimas ha sido tardío, lo que se evidencia en

[...] los niveles de cobertura de todos los componentes de la política son insuficientes. La atención humanitaria de emergencia, es el componente que mejores resultados ha registrado entre 1998 y 2002 tuvo una cobertura del 43\% de hogares desplazados registrados por la Red de Solidaridad Social, del 25\% de familias reportadas por coDHes, y ha cumplido con el 36\% del nivel establecido como meta en el Plan Estratégico. Al analizar únicamente los casos de desplazamiento individual, se observa que los datos son peores. En este caso, la cobertura es del 33\% de los despla-

6 El cual es un instrumento de estimación y caracterización socio-demográfica de la población desplazada que opera desde 1995 bajo la responsabilidad de CODHES. 
zados registrados por la Red de Solidaridad Social, y del $15.32 \%$ de los reconocidos por codHes (2004).

\section{Distribución del desplazamiento por regiones en Colombia} El conflicto armado en Colombia ha tenido y mantiene diferentes actores en el transcurso de su historia y estos han venido cambiando en las diferentes décadas, como: grupos guerrilleros, grupos paramilitares, la fuerza pública, grupos no reconocidos al margen de la ley, entre otros, a los cuales se les atribuyen diferentes delitos de lesa humanidad, como lo es el desplazamiento forzoso. Esta práctica también ha tenido diferentes actores que la propagan de manera continua, sistemática y selectiva. Los grupos armados (combatientes) a los que se les atribuye esta práctica de manera continua, permanente y como medio para imponer su poder son los grupos guerrilleros y las bandas organizadas que se originaron después del proceso de desmovilización de los grupos paramilitares. Los primeros recurriendo a desplazamientos forzados de manera selectiva y los segundos, a desplazamiento forzados de manera masiva.

El país y en general la zonas rurales del país han evidenciado una práctica conocida como "tierra arrasada" la cual “consiste en el ejercicio de la violencia que no solo aniquila a las personas, sino que destruye el entorno material y simbólico de las víctimas. De esta manera el territorio se vuelve inhabitable por la propagación de las huellas de terror, lo que fuerza al éxodo de la población" (CNMH, 2013, p. 73). Práctica que como consecuencia trae el abandono parcial o total de la población, permitiendo acoger estos lugares como puntos estratégicos para los diferentes actores de conflicto. El desplazamiento forzado recoge un total de 5'700.000 víctimas provenientes de lugares como Santa Marta, Turbo, Apartadó, El Carmen del Bolívar, Medellín, Riosucio, Buenaventura, 
San José del Guaviare, Tumaco, Puerto Asís, Tame, Tierralta, Tibú y Valledupar.

El Ruv establece que del año 1996 al 2002 hubo un aproximado de 2’014.893 desplazados, y de igual manera se presentó una suma anual entre el año 2000 al 2003 que superó las 300.000 personas. Para la fecha, la cifra aproximada es de 77.000 Di (RUv, 2014).

Para mayo de 2104 los departamentos más afectados con la recepción de desplazados son Bogotá, con 14.630; Valle del Cauca con 13.764; Antioquia con 10.671; Nariño con 9.029 y Cauca con 6.550 DI (RUv, 2014); lo cual reivindica la eventual preferencia de los desplazados internos a recurrir a trasladarse a las ciudades principales del país (Alfonso, 2011, p. 4). ${ }^{7}$

Son 1.116 municipios que registraron la expulsión de la población como consecuencia del conflicto armado, lo que representa un $97 \%$ del territorio nacional, a pesar de ello, el fenómeno no afectó por igual los distintos territorios ya que 139 municipios registraron más de 10.000 desplazados entre 1996 y 2012, lo que equivale al 74\% de la población desplazada, otros 57 municipios registraron más de 20.000 , otros 26 municipios mostraron más de 30.000, 12 municipios más reportaron más de 40.000 y nueve municipios más con 50.000 desplazados (CNMH, 2013, p. 76).

\section{Proyección de la situación actual}

Desde el año 1996 hasta el 2002 el desplazamiento en Colombia tuvo un incremento de sus cifras lo que ha llevado a que en

$7 \quad$ Al finalizar 2009 se registraron 3’303.970 personas desplazadas por los violentos a cambiar de lugar de residencia, de los cuales el 29\% de los desplazados había migrado dentro del mismo municipio, mientras que el 71\% se dirigió a lugares más lejanos del lugar de origen de sus municipios, específicamente hacia la capital. Esta eventual preferencia se reivindica con las cifras actuales del RUv. 
2004 la Corte Constitucional por medio de la ya mencionada Sentencia T 025-04 haya referido a la existencia de un "estado de cosas inconstitucional". Durante esta fase se presentaron dos tipos de desplazamiento, el primero que es el desplazamiento forzado individual, que comprendió el 73\% del total de desplazados, y el denominado desplazamiento forzado masivo, que abarcó el 27\% restante (cNMH, 2013, p. 74).

Sin embargo, alrededor del 60\% de los desplazados internos provienen de las áreas rurales del país y en muchos casos estas personas no han tenido la oportunidad de haber estado en otras ciudades del país. Algunos estudios sobre el desplazamiento interno en Colombia utilizan el sistema conocido como índice de calidad de vida, el cual se emplea para evaluar aquellas condiciones de vida de la población afectada y lo comparan con el estándar mínimo de vida constitucional (Piñeros, 2012, p. 177). En este caso se ven por debajo del promedio.

Una de las características que desarrolla esta modalidad de violencia radica en que la población más afectada resultan ser los niños, las mujeres, los adultos mayores de edad, los pueblos indígenas y afro colombianos (codHes, 1999). Aquí se constata que el promedio de edad de las personas desplazadas que parten de sus lugares de origen de manera individual es de un promedio de 23 años (Carrillo, 2009, p. 530).

Las estadísticas no producen una grata sensación debido a ciertos factores como la cobertura de la educación, la salud y la falta de trabajo (Piñeros, 2012, p. 194). ${ }^{8}$ Gracias a algunos estudios se observa que

8 Por otro lado y de conformidad con lo expresado por la Corte Constitucional, la cobertura se ha visto estancada, pero también su sostenibilidad en el tiempo como lo señala Piñeros Mendoza en su estudio, en el cual señala: "hay retroceso en el cumplimiento en alguno de los derechos analizados al menos en el 20\% de los 
[...] las personas provenientes del conflicto armado, presentan un déficit educativo y académico, dado que las estadísticas propuestas informan lo siguiente: el 11\% de los desplazados no tienen educación, el 2\% tienen estudios técnicos o profesionales (o al menos cursado un año), el $40 \%$ no completó su primaria básica de educación, el 25\% sostiene estudios de bachillerato (al menos un año), y el $22 \%$ restante completo la primaria básica de educación.

Estas estadísticas fueron realizadas a la población vulnerable en calidad de mayoría de edad (Carrillo, 2009, p. 535). La educación constituye un aspecto determinante para la obtención de un trabajo digno y con una justa remuneración, que, de tener más cobertura, se propiciarían mejores condiciones de vida para los desplazados por el conflicto.

Frente a la pobreza en cabeza de los desplazados, los estudios arrojan como resultado que la población desplazada se encuentra en situación de pobreza y en algunos casos de pobreza extrema. Según las diferentes fuentes, la capital ha tenido gran acogida por parte de los desplazados, pero también es evidente el crecimiento de la pobreza y de la falta de empleo para las víctimas del conflicto. Existe un empeoramieno en los hogares de las familias desplazadas, ello en cuanto a que "el 83\% de los desplazados estaría en condición de indigencia. Según el mismo estudio el 10\% de los hogares desplazados deben

hogares; el mayor retroceso se presenta en los derechos a la salud (39\%), la alimentación (38\%) y la generación de ingresos (36\%), lo que confirma que son los menos sostenibles en la política de atención a los desplazados", como objetivos de la Ley 387 de 1997 se encuentra lo que es la asistencia humanitaria y la estabilidad económica de los desplazados. El objeto de la ley no ha tenido un desarrollo óptimo frente a estas situaciones ya que no representa una garantía a la dignidad y de los derechos fundamentales a este grupo afectado de personas. 
enviar a sus niños y adolescentes (7 años a 17 años) a trabajar, y que por lo menos en el 17\% de las familias desplazadas se encontraba una mujer en embarazo" (Piñeros, 2012, p. 194). Por otra parte se encuentran las grandes falencias que han tenido las diferentes políticas implementadas por los distintos periodos presidenciales, no solamente frente a la cobertura de los planes de gobierno, sino de su inclusión social, los índices de protección y cobertura de derechos fundamentales como educación y salud, entre otros, no han tenido una satisfacción integral a esta población afectada, específicamente a la mujer, la niñez y la adolescencia, y esto se presenta en cuanto a las notables diferencias que mantenían los distintos registros, y las víctimas que se conocían.

Es pertinente traer a colación las cifras dadas en cuanto a quienes son cabeza de familia: siguiendo el análisis de Internal Displacement in Colombia: Humanitarian, Economic and Social Consequence in Urban Settings and Current Challenges", las cifras de quienes son cabezas de familia se distribuyen de la siguiente manera: el 51,2\% son hombres cabeza de familia, el 39,2\% son personas que se sostienen individualmente y el 9,6\% son mujeres cabeza de familia (Carrillo, 2009, p. 539).

\section{Conclusiones parciales}

Podríamos concluir de esta parte de la investigación cuál es la posición que mantiene Colombia en la actualidad, de la mano de los índices internacionales sobre desplazamiento interno, que no es alentadora visto desde una perspectiva en relación con otros Estados. Acorde con las cifras del IDMc, entre los países más afectados por el desplazamiento en Latinoamérica encontramos a México y Guatemala, ello se debe a distintos factores, sin embargo las cifras de estos dos países no superan el 10\% que tiene Colombia. Entre los factores más relevantes 
que ha tenido el país es el hecho de que un $27 \%$ de los desplazamientos internos en Colombia (CNMH, 2013) se haya dado de forma masiva; y por otro lado, está la situación de que aquí las víctimas del desplazamiento forzoso prefieran desplazarse a las ciudades principales del país. Estas dos situaciones hacen la problemática del desplazamiento uno de los problemas más perceptibles en la sociedad y en los medios de comunicación. Todo lo contrario a lo que sucede en los demás países del continente americano, dado que, si se presenta el desplazamiento, este se da en formas y cantidades diferentes a las que se presentan en Colombia. ${ }^{9}$

Esta situación debe convertirse en uno de los puntos más importantes a tratar de ahora en adelante, el hecho de que Colombia ostente una cifra de 4'900.000 a 5'500.000 millones de personas víctimas por esta modalidad empleada por los grupos armados da a entender la magnitud del conflicto y la falta de intervención estatal en la que haya podido incurrir el Estado desde 1985 a la actualidad.

\section{Segunda parte. Condenas de la Corte Interamericana de Derechos Humanos por desplazamiento forzado en Colombia}

Habiendo ya definido desplazamiento forzado y con ello la posición de Colombia a nivel internacional en relación a las cifras de desplazamiento mundial, se procederá a hacer un

\footnotetext{
9 Basta con observar algunos casos como los sucesos presentados en San Carlos o El Salado, Bolívar, en los cuales se presentaron desplazamientos forzosos a través del mencionado desplazamiento masivo; el Grupo de Memoria Histórica registro un abandono parcial o total de 54 de 74 veredas en el Municipio de San Carlos y, en el caso de El Salado, un abandono durante dos años por parte de sus habitantes (cnmh, 2013). Estos casos demuestran la diferencia abismal que existe con otros países, y más con los países latinoamericanos.
} 
análisis sobre condenas de la Corte Interamericana de Derechos Humanos (en adelante, Corte IDH) contra Colombia, basándonos en un método mixto entre análisis de caso y una metodología descriptiva sobre la circunstancia en concreto.

Lo importante aquí es medir el nivel de cumplimiento de Colombia respecto de las órdenes dictadas por la Corte IDH en relación con los casos que han sido objeto de investigación, para ello al final del análisis descriptivo realizaremos una tabulación de la información obtenida presentando así los resultados sobre el cumplimiento de las órdenes dictadas a Colombia sobre desplazamiento forzado aproximadamente desde el año 2004.

\section{Caso de la masacre de Mapiripán vs. Colombia (Corte IDH, 2005) $)^{10}$}

En el año de 1997 el Municipio de Mapiripán, en el Departamento del Meta, fue abatido por una serie de asesinatos, torturas y masacres a lo que se le conoció como "la masacre de Mapiripán”, en que, de acuerdo con los relatos de las víctimas y los hechos aceptados por la Corte IDH, paramilitares en colaboración de las fuerzas militares de nuestro país permitieron el acceso al municipio para proceder a asesinar a civiles inocentes, que según lo narrado se creía eran colaboradores de la guerrilla colombiana. ${ }^{11}$

10 Se relaciona la fecha en que tuvieron lugar los hechos de la masacre de Mapiripán, aceptados por el Estado colombiano y por la Corte Interamericana de Derechos Humanos en sentencia de la Corte Interamericana de Derechos Humanos Masacre de Mapiripán, con fecha 5 de septiembre de 2005.

11 Este caso fue llevado ante la Corte IDH el 15 de septiembre de 2005 (ocho años después de la masacre) por las graves violaciones de derechos humanos causadas en medio del conflicto armado interno en Colombia, que lamentablemente aún están vigentes. Además, es uno de los primeros casos en los cuales la Corte IDH 
La Corte IDH condena a Colombia por este caso en razón de que los pobladores afectados por el desplazamiento puedan regresar regresar o retornar a sus hogares en condiciones de seguridad (Corte IDH, Colombia, 2004), ${ }^{12}$ actualmente el caso es objeto de estudio mediante Resolución de la Corte IDH, se mantiene bajo supervisión de cumplimiento como uno de los puntos pendientes de acatamiento.

La Corte IDH $^{13}$ basa su declaración en lo contenido en la Sentencia T-025 de 22 de enero de 2004, emitida por la Sala Tercera de Revisión de la Corte Constitucional, así como en un informe emitido por el Ministerio de Defensa Nacional de la República de Colombia y también en un informe de la Alta Comisionada de las Naciones Unidas para los Derechos $\mathrm{Hu}^{-}$ manos sobre la situación de los derechos humanos en Colombia, y enfatiza que es necesario brindar una ayuda primordial a madres que son cabeza de familia y a través de mecanismos efectivos como leyes o políticas públicas que se implementen y generen un avance con relación a esta situación. Así pues, en conjunto con la Sentencia T-025 de 2004 que ordena al Estado colombiano a brindar una colaboración íntegra a las personas víctimas de desplazamiento forzado, la Corte IDH basa sus condenas persiguiendo el mismo fin que es resarcir

condena por desplazamiento forzado y sirve como base para manifestarse sobre otras decisiones que ha tomado respecto de este tema.

12 Sentencia de la Corte Interamericana de Derechos Humanos Masacre de Mapiripán de 5 de septiembre de 2005,p 181: “E1 Estado deberá realizar las acciones necesarias para garantizar las condiciones de seguridad para que los familiares de las víctimas, así como otros ex pobladores de Mapiripán, que se hayan visto desplazados, puedan regresar a Mapiripán, en caso de que así lo deseen, en los términos de los párrafos 311 y 313 de [la] Sentencia”. Recuperado de http://www.corteidh.or.cr/ docs/casos/articulos/seriec_134_esp.pdf

13 Ibíd. 
los daños causados por el conflicto armado interno y prevenir posibles situaciones de riesgo para el Estado.

\section{Caso masacre de Pueblo Bello vs. Colombia} (Corte IDH, 2006) $)^{14}$

Otro de los casos por desplazamiento forzado se dio a principios de la década de 1990, cuando un grupo de 60 hombres pertenecientes a grupos paramilitares llegaron al corregimiento de Pueblo Bello con el fin de realizar un ataque. Estando allí, y con lista en mano de las personas que consideraron "sospechosas", decidieron ingresar a las viviendas, desalojarlas y llevarse a los hombres que habitaban las mismas, secuestrándolos con la única finalidad de acabar con sus vidas en la plaza principal del corregimiento, logrando de esta forma sembrar miedo y terror entre los pobladores de la zona. ${ }^{15}$

El caso llega ante la Corte IDH el 23 de marzo de 2004 y, en Sentencia del 31 de enero de 2006, la Corte resuelve sobre el caso materia de estudio en donde especifica que, debido a que algunos de los casos desplazamiento forzado se presentan con posterioridad a la demanda ${ }^{16}$ presentada ante la Comisión IDH, la Corte no conocerá y no procederá a analizar las situaciones en relación con esas víctimas.

Debido a lo anterior, la Corte IDH en sus Resoluciones de Supervisión de Cumplimiento, establece que ha realizado un

14 Sentencia de la Corte IDH en relación a la masacre de Pueblo Bello, fecha de 31 de enero de 2006. Recuperado de http://www.corteidh.or.cr/docs/casos/articulos/ seriec_140_esp.pdf.

15 Respecto de esta sugerencia, si revisáramos los alegatos de este caso tendríamos por ende que revisar los alegatos de los demás casos y el tema sería mayor.

16 Demanda originada en las denuncias no 10566 y 11748 recibidas en la Secretaría de la Comisión el 12 de febrero de 1990 y 5 de mayo de 1997. Corte IDH, Caso de la masacre de Pueblo Bello vs. Colombia, Sentencia de 31 de enero de 2006. 
seguimiento primordialmente a la orden de brindar un tratamiento médico adecuado, haciendo necesaria la vinculación a algún tipo de sistema de salud colombiano. Respecto de la Orden de Garantía de Seguridad a los habitantes para que regresen a Pueblo Bello, la Corte no ha emitido un seguimiento en el cual establezca la situación actual de esas personas víctimas de desplazamiento forzado, toda vez que ha requerido al Estado información actualizada del mismo.

\section{Caso de las masacres de Ituango vs. Colombia (Corte IDH, 2007) ${ }^{17}$}

Esta situación de conflicto armado se presentó en los corregimientos de El Aro y La Granja en el departamento de Antioquia, en donde los grupos paramilitares o autodefensas, conocidas como AUc, con ayuda de fuerzas militares, quienes mostraron conductas omisivas, ingresaron a estos corregimientos, generando terror y caos, despojando a los pobladores de sus posesiones y obligándolos a desplazarse de esta región.

Las circunstancias de violencia generadas en las masacres de Ituango son otras de las causales por las cuales se condena al Estado colombiano en razón del desplazamiento forzado. La Corte IDH estableció en dicha condena ${ }^{18}$ que el Estado violó el artículo 22 de la Convención del Derecho de Circulación

17 Sentencia de la Corte IDH, caso de las masacres de Ituango vs. Colombia, Sentencia de 1 de julio de 2006. Recuperado de http://www.corteidh.or.cr/docs/ casos/articulos/seriec_148_esp.pdf

$18 \quad$ Ibíd., p. 147: "E1 Estado violó, en perjuicio de las personas desplazadas de E1 Aro y La Granja, quienes se encuentran señaladas en los párrafos 225 y 235 de esta Sentencia, el derecho de circulación y de residencia, consagrado en el artículo 22 (Derecho de Circulación y de Residencia) de la Convención, en relación con el artículo 1.1 (Obligación de Respetar los Derechos)". 
y Residencia luego de que la misma Corte realizara una interpretación sustancial de dicha norma.

La Corte IDH en su última Supervisión de Cumplimiento dice que este es un punto pendiente de acatamiento, hasta que el Estado no dé un Informe de Satisfacción respecto de la Orden. ${ }^{19}$

\section{Caso Valle Jaramillo vs. Colombia (Corte IDH, 2008) ${ }^{20}$}

El defensor de los derechos humanos Jesús María Valle Jaramillo a partir del año 1996, desde su oficina en Medellín, comenzó a realizar denuncias de actividades de grupos paramilitares en la zona, particularmente en el municipio de Ituango. En razón de ello el 27 de febrero de 1998 dos hombres ingresaron abruptamente a su oficina y le dispararon, causándole la muerte instantánea. En el lugar de los hechos se encontraban Nelly Valle Jaramillo y Carlos Fernando Jaramillo Correa, quienes fueron amarrados y amenazados con armas de fuego, viéndose obligado este último junto a su núcleo familiar a, inicialmente, desplazarse dentro de Colombia, para posteriormente exiliarse en el exterior, como consecuencia de las amenazas y hostigamientos recibidos, ya que era testigo

19 En cuanto a la obligación de realizar las acciones necesarias para garantizar las condiciones de seguridad para que los ex habitantes de los corregimientos de El Aro y La Granja que se hayan visto desplazados puedan regresar, según sea el caso y si así lo desearan, el Estado informó que la Alta Dirección de la Agencia Presidencial para la Acción Social constituyó el Equipo de Derechos Humanos y DiH para atender a la prevención y atención integral del desplazamiento forzado interno y que Acción Social ha implementado el "Sistema de Atención a Población Desplazada, Red Nacional de Juntos y Retornar es Vivir” Sentencia de la Corte IDH. Recuperado de http://www.corteidh.or.cr/docs/supervisiones/masacres_21_05_13.pdf

20 Sentencia de la Corte IDH, caso Valle Jaramillo y otros vs. Colombia, Sentencia de 27 de noviembre de 2008. Recuperado de http://www.corteidh.or.cr/docs/ casos/articulos/seriec_192_esp.pdf 
de los hechos ocurridos el 27 de febrero de 1998, y que el Estado lo había puesto en una situación de desprotección y vulnerabilidad.

La Corte acepta el reconocimiento de responsabilidad internacional efectuado por el Estado,y manifiesta que existió violación del derecho de circulación, reconocido en el artículo 22.1 de la Convención Americana sobre Derechos Humanos, en relación con la obligación general de garantía contemplada en el artículo 1.1 de la misma, en perjuicio de Carlos Fernando Jaramillo Correa, su cónyuge Gloria Lucía Correa, su hijo Carlos Enrique Jaramillo Correa y sus hijas, María Lucía Jaramillo Correa y Ana Carolina Jaramillo Correa, en los términos del párrafo 144 de esta Sentencia. ${ }^{21}$

La última resolución de la Corte $\mathrm{IDH}^{22}$, que trata sobre la obligación del Estado de garantizar la seguridad en caso de que Carlos Fernando Jaramillo Correa considere su retorno a Colombia, es la dictada el 28 de febrero de 2011. En esta se declara que la mencionada obligación aún queda pendiente de acatamiento, debido a que las víctimas, a través de sus representantes, consideraron que "las razones que hacen temer por la vida de las víctimas aún subsisten, y que el Estado no ha tomado medidas efectivas para transformar de manera real las difíciles condiciones que existen en el municipio de Ituango".

21 Para la Corte "el derecho de circulación y de residencia puede ser vulnerado por restricciones de facto si el Estado no ha establecido las condiciones ni provisto los medios que permiten ejercerlo".

22 Resolución de Cumplimiento, Corte IDH, caso Valle Jaramillo vs. Colombia, 28 de febrero de 2011. Recuperado de: http://www.corteidh.or.cr/docs/supervisiones/jaramillo_28_02_11.pdf 


\section{Caso Manuel Cepeda Vargas vs. Colombia (Corte IDH, 2010) ${ }^{23}$}

El caso hace referencia a la ejecución extrajudicial del que para entonces era senador de la república y líder político, el Señor Manuel Cepeda Vargas, en razón de la ola de masacres sobre determinados grupos políticos de la época de los años 1990.

El caso fue presentado ante la Comisión IDH en el año 2008 y fue decidida en Sentencia de Fondo para 2010, en donde se establecieron determinadas órdenes, una de ellas en relación con un alegado desplazamiento forzado por las condiciones de seguridad que se debían garantizar a los familiares de la víctima.

La Corte IDH dicta: ${ }^{24}$ "El Estado debe adoptar todas las medidas necesarias para garantizar la seguridad de los familiares del Senador Manuel Cepeda Vargas, y prevenir que deban desplazarse o salir del país nuevamente como consecuencia de actos de amenazas, hostigamiento o de persecución en su contra con posterioridad a la notificación de esta Sentencia”.

\section{Caso masacre de Santo Domingo vs. Colombia (Corte IDH, 2012) ${ }^{25}$}

Los hechos sucedidos en esta masacre datan del 13 de diciembre 1998, en una vereda de Arauca llamada Santo Domingo, donde en medio de un operativo militar desarrollado por las Fuerzas Militares en conjunto con la Fuerza Aérea Colom-

23 Sentencia Corte IDH, caso Cepeda Vargas vs. Colombia, Sentencia de 26 de mayo de 2010. Recuperado de: http://www.corteidh.or.cr/docs/casos/articulos/ seriec_213_esp.pdf

24 Ibíd. Puntos Resolutivos.

25 Sentencia Corte IDH, caso masacre de Santo Domingo vs. Colombia, Sentencia de 30 de noviembre de 2012. Recuperado de: http://www.corteidh.or.cr/ docs/casos/articulos/seriec_259_esp.pdf 
biana, cuya finalidad era decomisar la carga de un avión que aterrizó en la carretera cercana a la vereda, presumiblemente con dinero o armas destinadas al narcotráfico, estos fueron interrumpidos por disparos realizados por armas de largo alcance accionadas por la guerrilla. Al siguiente día, miembros del Ejército, que se encontraban a bordo de helicópteros, comenzaron a disparar contra las personas que estaban en la vereda, incluyendo la población civil, bombardeos que produjeron, además de muertes, daños a los bienes inmuebles. Esta situación llevó a que la población restante abandonara sus casas y se desplazara hacia poblaciones cercanas.

La Corte IDH considera que existió una violación al Artículo 22 de la Convención Americana de Derechos Humanos en razón de que la libre circulación hace parte del libre desarrollo de la personalidad y contribuye a una formación progresiva de las comunidades y es a través de esta disposición que se protege a las personas que han sido víctimas del desplazamiento forzado.

Sin embargo, pese a la violación cometida, el Estado resarció en gran parte los daños causados, reconstruyendo la población de Santo Domingo y prestando la ayuda necesaria a las personas que fueron obligadas a desplazarse del corregimiento. Actuación que es valorada por la Corte IDH aunque falta la identificación de ciertas víctimas y familias que por razones de seguridad y protección a sus vidas no han retornado a Santo Domingo, esto establecido en la Sentencia de Fondo, ya que la Corte IDH no se ha pronunciado en Resolución de Supervisión de Cumplimiento. 
Caso de las comunidades afrodescendientes desplazadas de la cuenca del río Cacarica (Operación Génesis) vs. Colombia (Corte IDH, 2013) ${ }^{26}$

La situación fáctica vivida en este caso es la incursión de Grupos Paramilitares o de Autodefensas Unidas de Colombia realizada a la cuenca del río Cacarica, donde habitan comunidades afrodescendientes y ancestrales que para la época eran poseedoras de estos territorios colectivos, en que, debido a las violentas confrontaciones entre varios grupos armados, se produjo un desplazamiento masivo de estas comunidades.

Según cifras registradas en la Defensoría del Pueblo (1997), ${ }^{27}$ más de 15.000 personas fueron desplazadas de la zona del Bajo Atrato Chocoano. Es precisamente debido a su ubicación estratégica que los grupos armados ilegales se disputan este territorio y como consecuencia de ello se produce este desplazamiento forzado.

La Corte IDH ${ }^{28}$ responde que el Estado colombiano es responsable en razón de una omisión ya que, viendo la situación presentada, no existió una manifestación inmediata para generar condiciones de seguridad a la población víctima de los ataques y que por tanto se vulneraron los Derechos establecidos en la Convención Americana de Derechos Humanos (Derecho de Circulación y Residencia) y su obligación de garantizar los derechos a la integridad personal y a no ser desplazados forzadamente.

26 Sentencia de Fondo de la Corte IDH, caso “Operación Génesis”vs. Colombia, con fecha 20 de noviembre de 2013. Recuperado de http://www.corteidh.or.cr/ docs/casos/articulos/seriec_270_esp.pdf

27 Ibíd., p. 35.

28 Ibíd., p. 104. 
Análisis gráfico. Reflexión y resultado de la investigación

\begin{tabular}{|c|c|}
\hline Nombre del caso & Masacre de Mapiripán. Gráfico n ${ }^{\circ} 1$ \\
\hline $\begin{array}{l}\text { Fecha de Sentencia } \\
\text { de Fondo }\end{array}$ & 15 de septiembre de 2005 \\
\hline Órdenes & $\begin{array}{l}\text { 1. Investigación por parte del Estado de los hechos del caso, } \\
\text { identificar, juzgar y sancionar a los responsables de la masacre } \\
\text { 2. Identificación de las víctimas de la masacre de Mapiripán y } \\
\text { sus familiares } \\
\text { 3. Mecanismo oficial de seguimiento del cumplimiento de las } \\
\text { reparaciones ordenadas } \\
\text { 4. Tratamiento adecuado a los familiares de las víctimas } \\
\text { 5. Garantías estatales de seguridad para los ex habitantes del } \\
\text { municipio de Mapiripán que decidan regresar } \\
\text { 6. Disculpa pública y reconocimiento de responsabilidad, a } \\
\text { nivel internacional } \\
\text { 7. Monumento } \\
\text { 8. Educación en derechos humanos para las Fuerzas Militares } \\
\text { 9. Publicación de las partes pertinentes de la sentencia }\end{array}$ \\
\hline $\begin{array}{l}\text { Sentencias de } \\
\text { Supervisión de } \\
\text { Cumplimiento }\end{array}$ & $\begin{array}{l}\text { - } \quad 8 \text { de julio de } 2009 \\
\text { - } \quad 8 \text { de febrero de } 2012 \\
\text { - } \quad 23 \text { de noviembre de } 2012\end{array}$ \\
\hline $\begin{array}{l}\text { Última Supervisión } \\
\text { de Cumplimiento }\end{array}$ & 23 de noviembre de 2012 \\
\hline $\begin{array}{l}\text { Cumplimiento } \\
\text { I Total (CT) } \\
\text { II Parcial (CP) } \\
\text { III No hay } \\
\text { cumplimiento NC) }\end{array}$ & $\begin{array}{l}\text { 1. Órdenes no 1,2,4,5,7: Se mantiene abierto el } \\
\text { procedimiento de Supervisión de Cumplimiento sobre los } \\
\text { puntos pendientes de acatamiento. (NC) } \\
\text { 2. Órdenes no } 3,6,8,9 \text { : La Corte IDH estima que se ha dado } \\
\text { un pleno cumplimiento (CT) }\end{array}$ \\
\hline
\end{tabular}

Nota: Lo resaltado en negrilla corresponde a las órdenes dictadas por la Corte IDH en relación con el desplazamiento forzado, en los casos de grupo se plantea una Orden de Garantías Estatales de Seguridad, en los casos particulares se manifiesta una orden de prevención a las personas que, en razón de la situación de conflicto presentada se vean amenazados o puedan llegar a ser víctimas al igual que sus familiares.

\begin{tabular}{|l|l|}
\hline \multicolumn{1}{|c|}{ Nombre del caso } & \multicolumn{1}{|c|}{ Pueblo Bello Gráfico n $^{\circ}$} \\
\hline $\begin{array}{l}\text { Fecha de Sentencia } \\
\text { de Fondo }\end{array}$ & 31 de enero de 2006 \\
\hline Órdenes & $\begin{array}{l}\text { 1. Investigación por parte del Estado de los hechos del caso, } \\
\text { identificación, juicio y sanción de los responsables }\end{array}$ \\
\hline
\end{tabular}




\begin{tabular}{|c|c|}
\hline Nombre del caso & Pueblo Bello Gráfico n ${ }^{\circ} 2$ \\
\hline Órdenes & $\begin{array}{l}\text { 2. Búsqueda, identificación y sepultura de las víctimas de la } \\
\text { masacre de Pueblo Bello } \\
\text { 3. Tratamiento médico o psicológico adecuado a los familiares } \\
\text { 4. Garantías estatales de seguridad para los familiares y ex } \\
\text { habitantes del municipio de Pueblo Bello que decidan regresar } \\
\text { 5. Disculpa pública y reconocimiento de responsabilidad } \\
\text { internacional } \\
\text { 6. Monumento } \\
\text { 7. Publicación de las partes pertinentes de la presente Sentencia }\end{array}$ \\
\hline $\begin{array}{l}\text { Sentencias de } \\
\text { Supervisión de } \\
\text { Cumplimiento }\end{array}$ & $\begin{array}{l}\text { - } 26 \text { de febrero de } 2008 \\
\text { - } \quad 8 \text { de febrero de } 2012\end{array}$ \\
\hline $\begin{array}{l}\text { Última Supervisión } \\
\text { de Cumplimiento }\end{array}$ & 8 de febrero de 2012 \\
\hline $\begin{array}{l}\text { Cumplimiento } \\
\text { I Total (CT) } \\
\text { II Parcial (CP) } \\
\text { III No hay } \\
\text { cumplimiento (NC) }\end{array}$ & $\begin{array}{l}\text { 1. El Estado ha cumplido con la orden del numeral } 7 \text { (C.T) } \\
\text { 2. En relación con el numeral } 1^{\circ} \text {, la Corte IDH estima que } \\
\text { debido a la falta de información brindada por el Estado sobre } \\
\text { las medidas adoptadas no es posible determinar si se ha dado } \\
\text { cumplimiento o no sobre esta orden } \\
\text { Respecto de las otras órdenes, en las Sentencias de Supervisión } \\
\text { de Cumplimiento la Corte no manifiesta si existe un } \\
\text { cumplimiento parcial o total de las órdenes emitidas, por lo tanto } \\
\text { se infiere que aún no hay cumplimiento (NC) }\end{array}$ \\
\hline Nombre del caso & Masacre de Ituango, Gráfico n 3 \\
\hline $\begin{array}{l}\text { Fecha de Sentencia } \\
\text { de Fondo }\end{array}$ & 1 de julio de 2006 \\
\hline Órdenes & $\begin{array}{l}\text { 1. Investigación por parte del Estado de los hechos del caso, } \\
\text { identificación, juicio y sanción de los responsables } \\
\text { 2. Tratamiento adecuado a los familiares de las víctimas } \\
\text { 3. Garantías estatales de seguridad para los ex habitantes del } \\
\text { municipio de Ituango que decidan regresar } \\
\text { 4. Disculpa pública y reconocimiento de responsabilidad } \\
\text { internacional } \\
\text { 5. Programa de vivienda } \\
\text { 6. Placa } \\
\text { 7. Educación en derechos humanos } \\
\text { 8. Publicación de las partes pertinentes de la Sentencia en un } \\
\text { diario de circulación Nacional }\end{array}$ \\
\hline
\end{tabular}




\begin{tabular}{|c|c|}
\hline Nombre del caso & Masacre de Ituango, Gráfico n ${ }^{\circ} 3$ \\
\hline $\begin{array}{l}\text { Sentencias de } \\
\text { Supervisión de } \\
\text { Cumplimiento }\end{array}$ & $\begin{array}{l}\text { - } \quad 8 \text { de febrero de } 2012 \\
\text { - } 28 \text { de febrero de } 2011 \\
\text { - } 22 \text { de diciembre de } 2010 \\
\text { - } \quad 7 \text { de julio de } 2009\end{array}$ \\
\hline $\begin{array}{l}\text { Última Supervisión } \\
\text { de Cumplimiento }\end{array}$ & 21 de mayo de 2013 \\
\hline $\begin{array}{l}\text { Cumplimiento } \\
\text { I Total (CT) } \\
\text { II Parcial (CP) } \\
\text { III No hay } \\
\text { cumplimiento (NC) }\end{array}$ & $\begin{array}{l}\text { 1. El Estado ha dado pleno cumplimiento a la orden } n^{\circ} 7,8 \\
\text { (CT) } \\
\text { 2. La Corte considera que se ha dado cumplimiento parcial a } \\
\text { las órdenes } n^{\circ} 5,6 \text {. (CP) } \\
\text { La Corte continuará supervisando el cumplimiento pendiente de } \\
\text { las órdenes } \mathrm{N}^{\circ} 1,2,3,4 \text {. (N.C) }\end{array}$ \\
\hline
\end{tabular}

\begin{tabular}{|c|c|}
\hline Nombre del caso & Manuel Cepeda Vargas, Gráfico ${ }^{\circ} 5$ \\
\hline $\begin{array}{l}\text { Fecha de Sentencia } \\
\text { de Fondo }\end{array}$ & 26 de mayo de 2010 \\
\hline Órdenes & $\begin{array}{l}\text { 1. Investigación por parte del Estado de los hechos del caso, } \\
\text { identificación, juicio y sanción de los responsables } \\
\text { 2. Garantías estatales de seguridad para el retorno a Colombia de } \\
\text { uno de los familiares de las víctimas } \\
\text { 3. Publicación de las partes pertinentes de la Sentencia en un } \\
\text { diario de circulación nacional } \\
\text { 4. Disculpa pública y reconocimiento de responsabilidad a nivel } \\
\text { internacional } \\
\text { 5. Realización de una publicación de un documental } \\
\text { audiovisual oficial acerca de la vida del senador } \\
\text { 6. Brindar una beca con el nombre del Senador Manuel } \\
\text { Cepeda } V \\
\text { 7. Tratamiento médico y psicológico que requieran las víctimas }\end{array}$ \\
\hline $\begin{array}{l}\text { Sentencias de } \\
\text { Supervisión de } \\
\text { Cumplimiento }\end{array}$ & $\begin{array}{l}\text { - } \quad 30 \text { de noviembre de } 2011 \\
\text { - } 8 \text { de febrero de } 2012\end{array}$ \\
\hline $\begin{array}{l}\text { Última Supervisión } \\
\text { de Cumplimiento }\end{array}$ & 08 de febrero de 2012 \\
\hline $\begin{array}{l}\text { Cumplimiento } \\
\text { I Total (CT) } \\
\text { II Parcial (CP) } \\
\text { III No hay } \\
\text { cumplimiento (NC) }\end{array}$ & $\begin{array}{l}\text { 1. El Estado ha dado pleno cumplimiento a las órdenes } n^{\circ} 3 \text { y } 4 \\
\text { (CT) } \\
\text { Quedan bajo supervisión de cumplimiento de la Corte las } \\
\text { órdenes } n^{\circ} 1,2,5,6 \text { y } 7\end{array}$ \\
\hline
\end{tabular}




\begin{tabular}{|l|l|}
\hline \multicolumn{1}{|c|}{ Nombre del caso } & \multicolumn{1}{|c|}{ Masacre de Santo Domingo, Gráfico n ${ }^{\circ}$ 6 } \\
\hline $\begin{array}{l}\text { Fecha de Sentencia } \\
\text { de Fondo }\end{array}$ & 30 de noviembre de 2012 \\
\hline Órdenes & $\begin{array}{l}\text { 1. Acto público y reconocimiento de responsabilidad a nivel } \\
\text { internacional } \\
\text { 2. Publicación de las partes pertinentes de la Sentencia } \\
\text { 3ratamiento integral en salud a las víctimas }\end{array}$ \\
\hline $\begin{array}{l}\text { Sentencias de } \\
\text { Supervisión de } \\
\text { Cumplimiento }\end{array}$ & Aún no cuenta con Supervisión de Cumplimiento \\
\hline $\begin{array}{l}\text { Última Supervisión } \\
\text { de Cumplimiento }\end{array}$ & Aún no cuenta con Supervisión de Cumplimiento \\
\hline $\begin{array}{l}\text { Cumplimiento } \\
\text { ITotal (CT) } \\
\begin{array}{l}\text { II Parcial (CP) } \\
\text { III No hay } \\
\text { cumplimiento (NC) }\end{array}\end{array}$ & Aún no cuenta con Supervisión de Cumplimiento \\
\hline
\end{tabular}

\begin{tabular}{|c|c|}
\hline Nombre del caso & Operación Génesis, Gráfico n ${ }^{\circ} 7$ \\
\hline $\begin{array}{l}\text { Fecha de Sentencia } \\
\text { de Fondo }\end{array}$ & 20 de noviembre de 2013 \\
\hline Órdenes & $\begin{array}{l}\text { 1. Investigación por parte del Estado de los hechos del caso, } \\
\text { identificación, juicio y sanción de los responsables } \\
\text { 2. Publicación de las partes pertinentes de la Sentencia } \\
\text { 3. Acto público de reconocimiento de responsabilidad } \\
\text { 4. Tratamiento médico adecuado } \\
\text { 5. Restitución por parte del Estado del respectivo uso, goce y posesión } \\
\text { de los territorios } \\
\text { 6. Garantías estatales de vida digna y de seguridad para el retorno a } \\
\text { los territorios restituidos }\end{array}$ \\
\hline $\begin{array}{l}\text { Sentencias de } \\
\text { Supervisión de } \\
\text { Cumplimiento }\end{array}$ & Aún no cuenta con Supervisión de Cumplimiento \\
\hline $\begin{array}{l}\text { Última Supervisión } \\
\text { de Cumplimiento }\end{array}$ & Aún no cuenta con Supervisión de Cumplimiento \\
\hline $\begin{array}{l}\text { Cumplimiento } \\
\text { I Total (CT) } \\
\text { II Parcial (CP) } \\
\text { III No hay } \\
\text { cumplimiento (NC) }\end{array}$ & Aún no cuenta con Supervisión de Cumplimiento \\
\hline
\end{tabular}


Estadístaicas del cumplimiento de las órdenes de la Corte IDH y cumplimiento de las órdenes respecto del desplazamiento forzado
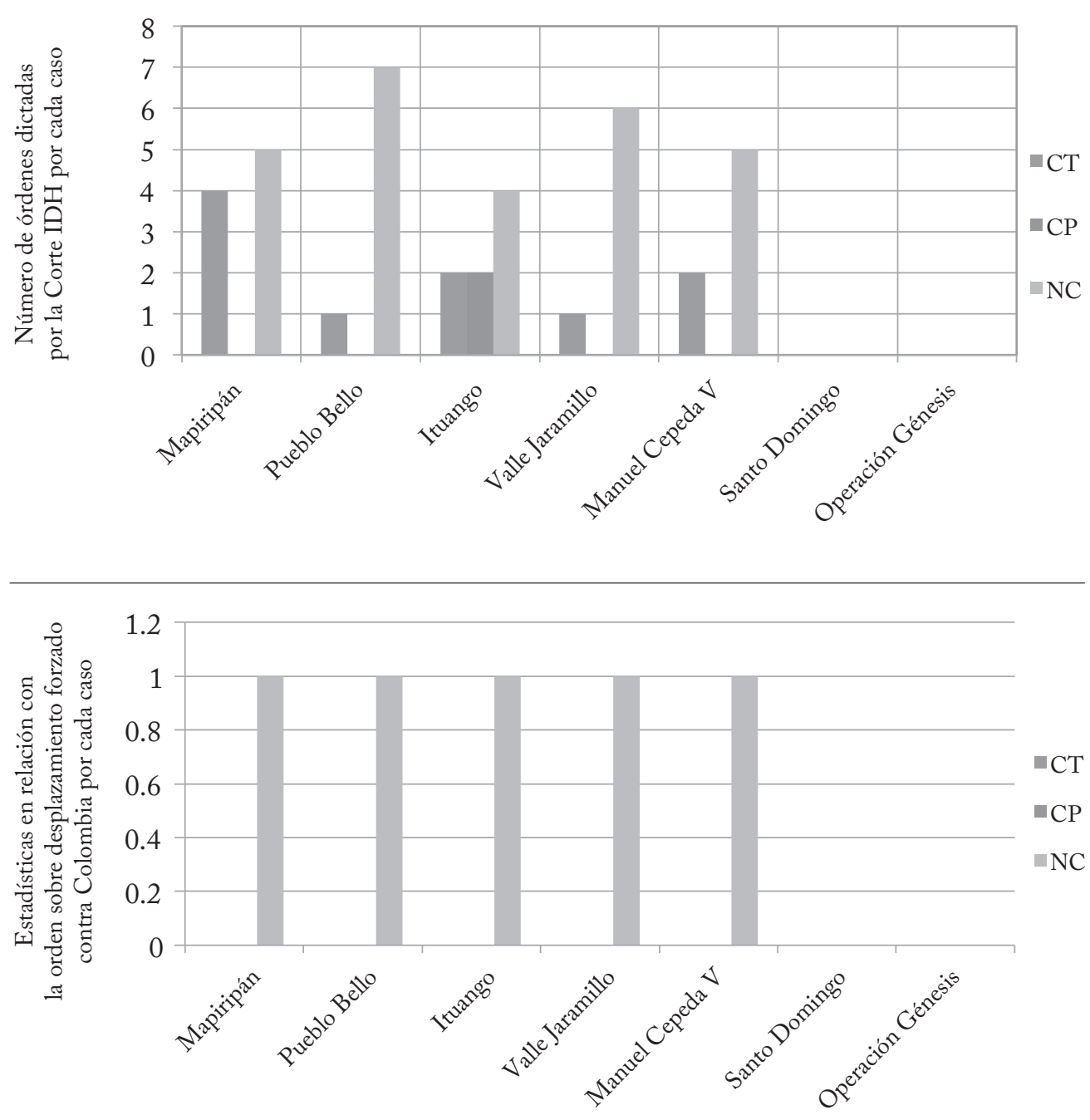

En los anteriores gráficos podemos observar dos situaciones: En un primer momento, los casos llevados ante la Corte IDH contra Colombia en temas relacionados con violación a los derechos humanos y, en segundo lugar, el cumplimiento de las órdenes contra el desplazamiento forzado como consecuencia del conflicto armado.

Frente a esta situación Colombia tiene un promedio de seis a nueve órdenes dictadas por la Corte IDH por cada caso, donde solo una de ellas corresponde a la Garantía de 
Seguridad para las personas víctimas del desplazamiento. Lastimosamente, Colombia respecto de esta orden tiene un incumplimiento total o nulo, lo que implicaría una mayor concentración respecto de este tema en el auge del proceso de paz en el cual se encuentra nuestro país, conjuntamente con el trabajo llevado a cabo con la creación de nuevas entidades que vigilan la protección a las víctimas como uno de los sectores más vulnerados dentro de nuestra sociedad.

\section{Conclusiones finales}

La tardía reglamentación de este fenómeno ha llevado a distintas consecuencias, la falta de cobertura representa un problema grave frente a la vulneración de derechos humanos, y observar que esta situación necesita una solución integral y que sea sostenible en el tiempo.

De las cifras analizadas se evidencia que, además de esta problemática social, también se está complementado por circunstancias que agravan la situación, como la falta de educación de las personas víctimas del desplazamiento o la falta de garantía por parte del Estado y de los gobiernos de turno para implementar políticas que contribuyan a disminuir las cifras alarmantes de desplazamiento interno.

\section{Sobre el análisis estadístico y de seguimiento}

\section{a las sentencias}

Colombia tiene siete condenas ante la Corte IDH por temas relacionados con desplazamiento forzado, todos ellos causados al margen de un conflicto armado interno, de las cuales a ninguna se ha dado un pleno cumplimiento o tan siquiera un cumplimiento parcial. El país, no obstante una continua condena por desplazamiento forzado desde 2005 no ha podido responder a los llamados de la instancia internacional. 
De todas las órdenes dictadas por la Corte IDH contra Colombia, existe un tiempo aproximado de 20 años entre el transcurso de las circunstancias fácticas, la denuncia de los hechos y la sentencia de fondo que ordena el cumplimiento de una Garantía de Seguridad para las personas víctimas del desplazamiento y la Resolución de Supervisión de Cumplimiento, que demuestra cuál ha sido el cumplimiento respecto de estas órdenes.

Según el Centro Nacional de Memoria Histórica en su informe de 2013, el desplazamiento forzado puede presentarse en dos modalidades: una, conocida como desplazamiento forzado selectivo, que aplica a una persona o un grupo determinado de personas víctimas como lo evidenciado en dos de los casos estudiados, a saber: Manuel Cepeda Vargas y Valle Jaramillo, y, otra, un desplazamiento forzado masivo, que aplica para una comunidad determinada lo que se evidencia en las cinco sentencias restantes, como consecuencia del fenómeno conocido como "tierra arrasada". ${ }^{29}$

\section{Sobre los fundamentos jurídicos de las condenas por desplazamiento forzado en el Sistema Interamericano}

El país debe garantizar acceso, retribución y devolución (denominada internamente Restitución, Ley 1448 de 2011) a las personas desplazadas sobre sus propiedades y es a ello a lo que se dirige la Corte IDH con sus puntos resolutivos, prevaleciendo el interés general,y la protección de derechos humanos

29 El fenómeno conocido como "tierra arrasada” es la consecuencia de la incursión de grupos alzados en armas a los distintos municipios, los cuales son obligados a través de la fuerza a abandonar sus tierras y con gran temor entregar sus pertenencias, siendo despojados de sus propios territorios. Recuperado de un informe del Centro Nacional de Memoria Histórica de: http://www.centrodememoriahistorica.gov.co/ en/iniciativas-de-memoria/memorias-desde-la-region?start=10 
sobre situaciones de conflicto armado interno que generan desplazamiento de zonas donde los terrenos son fértiles y facilitan los cultivos, la siembra, la producción de la tierra y que son fuente de ingresos económicos para la gran mayoría de población que vive de la agricultura, pero que por motivos adversos y ajenos a su voluntad deben ser abandonados.

Otra de las conclusiones a las cuales es posible llegar luego de esta investigación es la falta de una norma aplicable a nivel internacional frente al caso de desplazamiento forzado interno, siempre se usa la figura del artículo 22.1 de la Convención Americana de Derechos Humanos ${ }^{30}$ que es el Derecho de Circulación y de Residencia donde se establece que: "Toda persona que se halle legalmente en el territorio de un Estado tiene derecho a circular por el mismo y, a residir en él con sujeción a las disposiciones legales". Esto debido a que Colombia es uno de los pocos países que se ve afectado por la problemática del desplazamiento forzado y que a su vez ratificó esta Convención para hacerla parte del bloque de constitucionalidad del Estado.

Es por ello que el pronunciamiento de la Corte sobre el desplazamiento interno en este país basa su criterio en gran parte en jurisprudencia desarrollada por la Corte Constitucional colombiana, a saber: la Sentencia T-025 de 2004 que establece cierto tipo de órdenes a organismos defensores de derechos humanos en nuestro país, como lo es la Procuraduría General de la Nación, y en conjunto con la Defensoría del Pueblo, para realizar un seguimiento continuo a la implementación de las solicitudes emitidas en dichas sentencias en

30 Convención Americana sobre Derechos Humanos, Art. 22.1 sobre el Derecho a la Circulación y la Residencia. Recuperado de http://www.oas.org/dil/esp/ tratados_b-32_convencion_americana_sobre_derechos_humanos.htm 
pro de la población desplazada como el sector afectado por la violencia.

\section{Referencias bibliográficas}

ACNUR (abril de 2013) IDMc: 28,8 millones de desplazados internos en el mundo en 2012. Recuperado de http://www. acnur.org/t3/noticias/noticia/idmc-288-millones-de-desplazados-internos-en-el-mundo-en-2012-cifra-recordque-incluye-un-aumento-de-cinco-veces-en-siria/.

Alfonso, Ó. A. (2011). La geografía del desplazamiento forzado reciente en Colombia. [Versión de Publicaciones Externado]. Recuperado de http://portal.uexternado.edu.co/pdf/1_ facultadEconomia/Publicaciones/DocumentosDeTrabajo/ documentoDeTrabajoNo332011OscarAAlfonso\%20R..pdf

Carrillo, A. (2009). Internal displacement in Colombia: Humanitarian, economic and social consequences in urban settings and current challenges. International Review of the Red Cross, 91(875), 527-546. Doi: 10.1017/S1816383109990427.

Comisión de Derechos Humanos (1998). Principios Rectores de los Desplazamientos Internos. En Informe del Representante del Secretario General, Sr. Francis M. Deng, con arreglo a la resolución 1997/39 de la Comisión de Derechos Humanos. Recuperado de http://www.acnur.org/t3/filead$\mathrm{min} /$ scripts/doc.php?file=biblioteca/pdf/0022

Convención Americana sobre Derechos Humanos. Artículo 22.1 sobre el Derecho a la Circulación y la Residencia. Recuperado de http://www.oas.org/dil/esp/tratados_b-32_convencion_americana_sobre_derechos_humanos.htm

Corte Interamericana de Derechos Humanos. Página web. Recuperado de http://www.corteidh.or.cr

Corte Interamericana de Derechos Humanos. Sentencia de Fondo la Corte Interamericana de Derechos Humanos Masacre 
de Mapiripán vs. Colombia de 05 de septiembre de 2005. Recuperado de: http://www.corteidh.or.cr/docs/casos/articulos/seriec_134_esp.pdf

Corte Interamericana de Derechos Humanos. Caso de la Masacre de Mapiripán vs. Colombia. Supervisión Cumplimiento de Sentencia. Resolución del Presidente de la Corte Interamericana de Derechos Humanos de 8 de febrero de 2012. Recuperado de http://www.corteidh.or.cr/docs/supervisiones/ mapiripan_23_11_12.pdf

Corte Interamericana de Derechos Humanos. Caso de la Masacre de Mapiripán vs. Colombia. Supervisión de Cumplimiento de Sentencia. Resolución de la Corte Interamericana de Derechos Humanos de 08 de julio de 2009. Recuperado de http://www.corteidh.or.cr/docs/supervisiones/mapiripan_08_07_09.pdf

Corte Interamericana de Derechos Humanos. Caso de la Masacre de Mapiripán vs. Colombia. Supervisión de Cumplimiento de Sentencia. Resolución de la Presidenta de Corte Interamericana de Derechos Humanos de 26 de noviembre de 2008. Recuperado de http://www.corteidh.or.cr/docs/ supervisiones/mapiripan_26_11_08.pdf

Corte Interamericana de Derechos Humanos. Sentencia de Fondo la Corte Interamericana de Derechos Humanos en relación a la Masacre de Pueblo Bello vs. Colombia de 31 de enero de 2006. Recuperado de: http://www.corteidh.or.cr/ docs/casos/articulos/seriec_140_esp.pdf

Corte Interamericana de Derechos Humanos. Caso de la Masacre de Pueblo Bello vs. Colombia. Supervisión Cumplimiento de Sentencia. Resolución del Presidente de la Corte Interamericana de Derechos Humanos de 8 de febrero de 2012. Recuperado de http://www.corteidh.or.cr/docs/supervisiones/bello_08_02_12.pdf 
Corte Interamericana de Derechos Humanos. Caso de la Masacre de Pueblo Bello vs. Colombia. Supervisión de Cumplimiento de Sentencia. Resolución de la Presidenta de Corte Interamericana de Derechos Humanos de 26 de noviembre de 2008. Recuperado de http://www.corteidh.or.cr/docs/ supervisiones/bello_26_11_08.pdf

Corte Interamericana de Derechos Humanos. Sentencia de Fondo la Corte Interamericana de derechos humanos caso de las Masacres de Ituango vs. Colombia de 1 de julio de 2006 recuperado de: http://www.corteidh.or.cr/docs/casos/ articulos/seriec_148_esp.pdf

Corte Interamericana de Derechos Humanos. Caso de las Masacres de Ituango vs. Colombia. Supervisión de Cumplimiento de Sentencia. Resolución de la Corte Interamericana de Derechos Humanos de 21 de mayo de 2013. Recuperado de http://www.corteidh.or.cr/docs/supervisiones/masacres_21_05_13.pdf

Corte Interamericana de Derechos Humanos. Caso de las Masacres de Ituango vs. Colombia. Supervisión de Cumplimiento de Sentencia. Resolución del Presidente de la Corte Interamericana de Derechos Humanos de 8 de febrero de 2012. Recuperado de http://www.corteidh.or.cr/docs/supervisiones/ituango_08_02_12.pdf

Corte Interamericana de Derechos Humanos. Caso de las Masacres de Ituango vs. Colombia. Supervisión de Cumplimiento de Sentencia. Resolución de la Corte Interamericana de Derechos Humanos 28 de febrero de 2011. Recuperado de http://www.corteidh.or.cr/docs/supervisiones/ituango_28_02_11.pdf

Corte Interamericana de Derechos Humanos. Caso de las Masacres de Ituango vs. Colombia. Supervisión de Cumplimiento de Sentencia. Resolución del Presidente de la Corte 
Interamericana de Derechos Humanos de 22 de diciembre de 2010. Recuperado de http:/www.corteidh.or.cr/docs/ supervisiones/ituango_22_12_10.pdf

Corte Interamericana de Derechos Humanos. Caso de las Masacres de Ituango vs. Colombia. Supervisión de Cumplimiento de Sentencia. Resolución de la Corte Interamericana de Derechos Humanos de 07 de julio de 2009. Recuperado de: http://www.corteidh.or.cr/docs/supervisiones/ituango_07_07_09.pdf

Corte Interamericana de Derechos Humanos. Sentencia de Fondo caso Valle Jaramillo y otros vs. Colombia, Sentencia de 27 de noviembre de 2008. Recuperado de http://www.corteidh. or.cr/docs/casos/articulos/seriec_192_esp.pdf

Corte Interamericana de Derechos Humanos. Caso Valle Jaramillo y otros vs. Colombia. Supervisión de Cumplimiento de Sentencia. Resolución del Presidente de la Corte Interamericana de Derechos Humanos de 8 de febrero de 2012. Recuperado de http://www.corteidh.or.cr/docs/supervisiones/jaramillo_08_02_12.pdf

Corte Interamericana de Derechos Humanos. Caso Valle Jaramillo y otros vs. Colombia. Supervisión de Cumplimiento de Sentencia. Resolución de la Corte Interamericana de Derechos Humanos de 15 de mayo de 2011. Recuperado de http://www.corteidh.or.cr/docs/supervisiones/jarami1lo_15_05_11.pdf

Corte Interamericana de Derechos Humanos. Caso Valle Jaramillo y otros vs. Colombia. Supervisión de Cumplimiento de Sentencia. Resolución de la Corte Interamericana de Derechos Humanos de 28 de febrero de 2011. Recuperado de http://www.corteidh.or.cr/docs/supervisiones/jarami1lo_28_02_11.pdf 
Corte Interamericana de Derechos Humanos. Caso Valle Jaramillo y otros vs. Colombia. Supervisión de Cumplimiento de Sentencia. Resolución del Presidente de la Corte Interamericana de Derechos Humanos 21 de diciembre de 2010. Recuperado de http://www.corteidh.or.cr/docs/supervisiones/jaramillo_21_12_10.pdf

Corte Interamericana de Derechos Humanos. Sentencia de Fondo, caso Manuel Cepeda Vargas vs. Colombia, Sentencia de 26 de mayo de 2010. Recuperado de http://www.corteidh. or.cr/docs/casos/articulos/seriec_213_esp.pdf

Corte Interamericana de Derechos Humanos. Caso Manuel Cepeda Vargas vs. Colombia. Supervisión de Cumplimiento de Sentencia. Resolución del Presidente de la Corte Interamericana de Derechos Humanos de 8 de febrero de 2012. Recuperado de http://www.corteidh.or.cr/docs/supervisiones/cepeda_08_02_12.pdf

Corte Interamericana de Derechos Humanos. Caso Manuel Cepeda Vargas vs. Colombia. Supervisión de Cumplimiento de Sentencia. Resolución de la Corte Interamericana de Derechos Humanos de 30 de noviembre de 2011. Recuperado de http://www.corteidh.or.cr/docs/supervisiones/ cepeda_30_11_11.pdf

Corte Interamericana de Derechos Humanos. Sentencia de Fondo, caso Masacre de Santo Domingo vs. Colombia, Sentencia de 30 de noviembre de 2012. Recuperado de http:// www.corteidh.or.cr/docs/casos/articulos/seriec_259_esp.pdf Corte Interamericana de Derechos Humanos. Sentencia de Fondo, caso "Operación Génesis" vs Colombia de 20 de noviembre de 2013, recuperado de http://www.corteidh. or.cr/docs/casos/articulos/seriec_270_esp.pdf

IDMc. Convención Americana sobre Derechos Humanos suscrita en la Conferencia Especializada Interamericana sobre 
Derechos Humanos. Recuperado de http://www.internaldisplacement.org. 2013. http://www.internal-displacement. org/americas/colombia/.

Internal Displacement Monitoring Center IDMC (2013). Recuperado de http://www.internal-displacement.org Pérez, B. (2014). El tema del desplazamiento interno en la agenda pública: Una comparación de su situación en México y Colombia. Cotidiano-Revista de la Realidad Mexicana, 28(183), 7-16.

Piñeros, A. (2012). El desplazamiento forzado en Colombia y la intervención del Estado. Revista de Economía Institucional, 13(26), 169-202.

Rojas Rodríguez, J. E. (1999). Un país que huye, vol. 1. [Versión de Biblioteca codHes]. Recuperado de http://www. codhes.org/index.php/2013-10-01-04-17-32/book/10unpaisquehuye1/8-codhes-bilioteca-comision-seguimiento. 


\title{
La discusión probatoria de las víctimas y la Sentencia T-025 de 2004 Una caracterización desde el constitucionalismo democrático
}

\author{
María Alejandra Lozano Amaya* \\ Ana Sofía Payán Rodríguez" \\ Luis Enrique Ruiz González
}

\section{Resumen}

Este artículo, a partir de algunas nociones sobre constitucionalismo democrático y el papel de las cortes constitucionales en los Estados constitucionales y democráticos, busca caracterizar a la Corte Constitucional con ocasión de la expedición de la Sentencia T-025 sobre desplazamiento forzado, en una

* Estudiante de octavo semestre, Facultad de Jurisprudencia de la Universidad del Rosario. Correo electrónico: lozano.maria@urosario.edu.co

** Estudiante de décimo semestre de la Facultad de Jurisprudencia de la Universidad del Rosario. Integrante del Grupo de Acciones Públicas de la Universidad del Rosario. Correo electrónico: anasofiapayan@hotmail.com

**** Politólogo y estudiante de décimo semestre de la Facultad de Jurisprudencia de la Universidad del Rosario. Integrante del Grupo de Acciones Públicas de la Universidad del Rosario. Correo electrónico: ruizg.luis@urosario.edu.co 
materia específica como es el aspecto probatorio para acreditar la condición de desplazado o víctima del conflicto e identificar la incidencia que la Sala Especial de Seguimiento tuvo en la garantía de los derechos de la población desplazada y en el diseño institucional de atención a las víctimas.

\section{Palabras clave}

Constitucionalismo democrático, jurisprudencia constitucional, Sentencia T-025 de 2004, desplazamiento forzado, flexibilidad probatoria.

\section{Introducción}

Durante las últimas décadas la sociedad colombiana se ha permeado por las consecuencias de la violencia interna, siendo foco de uno de los flagelos más apabullantes el desplazamiento forzado, circunstancia en la que las víctimas sufren la "vulneración múltiple, masiva y continua de los derechos fundamentales de los colombianos obligados a emigrar internamente" (CConst., SU1150/2000, E. Cifuentes Muñoz) causando una condición extrema de vulnerabilidad.

Con ocasión de los diez años de la Sentencia T - 025de 2004 de la Corte Constitucional, es el momento propicio para analizar y caracterizar ese proceso constitucional para la garantía de las víctimas de desplazamiento y, en general, para las víctimas del conflicto armado en Colombia.

Una manera de evaluar la efectiva protección de derechos es la valoración de la jurisprudencia, pues su apreciación permite comprender qué procesos ha realizado la administración de justicia para que la población desplazada logre, a pesar de la rigurosidad de la ley, reconstruir en el campo del derecho un hecho que por sus especificidades es prácticamente impo- 
sible de demostrar, siendo este un modo de no continuar con la conculcación de derechos.

Aunque el impacto de la sentencia T-025 de 2004 y de las providencias que se han proferido para el seguimiento en su cumplimiento pueden versar sobre diversos y complejos temas que afectan a la población desplazada, este artículo se enfoca en los asuntos probatorios que tienen que enfrentar los desplazados y otras víctimas, que en muchas ocasiones se traduce en una total desprotección y una denegación del conjunto de sus derechos.

Se ha dicho desde el inicio de la teoría probatoria, que esta debe cumplir con "una función social, una función humana individual [...] y una jurídica" (Parra Quijano, 1998, p. 4), pues, al requerir de una valoración probatoria sobre alguna circunstancia, surge entonces como una necesidad de las personas, en primera medida, para ser tenida en cuenta y, en segunda medida, para adquirir la certeza de unos hechos que pretenden funcionar como supuesto fáctico en la aplicación de determinada normativa.

Siendo el desplazamiento forzado una anomalía dentro de la sociedad que surgió con ocasión de la violencia interna, ha tenido un manejo complejo. Esto ha causado que las autoridades, que respondían a la administración de justicia, no conocieran el modo de valoración adecuado ante los hechos que correspondían a esta circunstancia, causándose continuas inconsistencias y haciendo más gravosas las violaciones de diferentes derechos, que de por sí se estaban causando a los nacionales con ocasión de este fenómeno.

El objetivo general de este artículo es evidenciar la problemática que enfrenta la población desplazada de acuerdo con los pronunciamientos de la Corte Constitucional, antes y con posterioridad a la Sentencia T-025, respecto de las exigencias 
que en materia de pruebas y acreditación de su condición de desplazado debían asumir y sin las cuales no podían ver garantizados sus derechos.

De este propósito surgen como objetivos específicos (i) caracterizar el funcionamiento de la Corte Constitucional desde la Sentencia T-025 de 2004 a partir de elementos teórico-conceptuales propios del constitucionalismo democrático y teorías sobre el papel de los tribunales constitucionales en los Estados constitucionales contemporáneos, (ii) demostrar la incidencia que la Corte Constitucional, de acuerdo con el constitucionalismo democrático, ha tenido en un diseño más adecuado de los procedimientos que garanticen los derechos de las víctimas del conflicto armado y (iii) mostrar la incidencia que los pronunciamientos constitucionales en materia probatoria, referentes a la población desplazada, han tenido en la política actual de atención y reparación a las víctimas.

A través de este artículo se mostrarán los resultados de un estudio descriptivo, por medio del análisis de los diferentes pronunciamientos que ha tenido la Corte Constitucional con el fin de darle un cumplimiento efectivo a la Sentencia T-025 de 2004. Es a través de la materialización y de la práctica donde encontramos la existencia de ciertas excepciones probatorias que son necesarias para recurrir a ellas en el momento en que la población desplazada deba demostrar su condición. A partir de esto se hará un análisis de las diferentes dificultades probatorias que tienen los desplazados en el momento de dar aplicación a los beneficios obtenidos a través de la Sentencia T-025 de 2004.

Visto lo anterior, se recopiló información concerniente a los diferentes pronunciamientos de la Corte Constitucional que tratan el tema específico de la acreditación de la condición de desplazados y las dificultades asociadas a este requisito. 
Pero es igualmente importante hacer un pronunciamiento sobre las diferentes teorías de constitucionalismo democrático, para de alguna forma enmarcar el papel de los jueces constitucionales dentro de las democracias y ver realmente la trascendencia de la sala especial de seguimiento de la T-025 de 2004 y el papel de la Corte Constitucional.

$\mathrm{El}$ artículo está dividido en tres partes. La primera de ellas hará una exposición sobre nociones conceptuales del constitucionalismo democrático a partir de autores como Robert Post y Reva Siegel, así como de doctrina sobre el papel de los jueces constitucionales en las democracias. A partir estos insumos se hará una descripción de la Corte Constitucional colombiana y su Sala Especial de Seguimiento a la sentencia T-025 de 2004.

En segundo lugar, se presentarán los pronunciamientos de la Corte que trataron el aspecto probatorio exigido a la población desplazada y su problemática asociada a la desprotección y desconocimiento de los derechos fundamentales de acceso a la administración de justicia y dignidad humana. Se describirá el debate probatorio que ha surgido con respecto a la población desplazada en las decisiones de la Corte Constitucional. Se realizará mediante el análisis de los pronunciamientos más importantes de la misma, que antecedieron a la sentencia al igual que los posteriores a la decisión judicial, con el fin de analizar si existen o no cambios jurisprudenciales en la interpretación jurídica que se ha dado a las excepciones o cargas probatorias que debe soportar la población desplazada.

En tercer lugar, se hará una relación de las soluciones jurídicas que planteaban esos pronunciamientos de la Corte con el marco jurídico actual de atención a las víctimas del cual es claro antecedente y, finalmente, se presentarán algunas conclusiones. 


\section{La Corte Constitucional y el constitucionalismo democrático}

La Corte Constitucional ha desempeñado un rol relevante en la protección y garantía de los derechos de la población desplazada y ha hecho esfuerzos importantes por superar ese estado de cosas inconstitucional que declara la Sentencia T-025. Precisamente, este estado de cosas inconstitucionales cuestiona la vigencia y efectividad de la Constitución misma y era de esperarse que la Corte, como guardiana de la integridad y supremacía constitucional, adoptara medidas que permitieran recuperar esa eficacia de la Constitución.

Es por esta razón que resulta relevante, para analizar el comportamiento de la Corte Constitucional frente a la problemática de la población desplazada, un marco teórico conceptual de análisis que permita describir la actividad de esta última en este contexto. Se proponen entonces como marco conceptual algunas nociones propias del constitucionalismo democrático, por cuanto este pretende identificar la relación entre la legitimidad y vigencia de las Constituciones, junto con las interpretaciones que hacen los entes judiciales encargados de esa labor y las perspectivas que diversos sectores de la sociedad tienen de las normas constitucionales.

Así, Robert Post y Reva Siegel (2013), como exponentes del constitucionalismo democrático, parten de los siguientes supuestos: En primer lugar, el debate, la discusión y el desacuerdo sobre las interpretaciones de la Constitución son una "condición normal para el desarrollo del derecho constitucional" (p.40).De hecho, para estos autores "aunque pareciera que estas luchas amenazan la legitimidad de la Constitución, el conflicto puede de hecho ayudar a sustentar su autoridad cuando se lo encamina de conformidad con las formas de comprender el ordenamiento constitucional" (Post y Siegel, 2013, p. 33). 
Post y Siegel proponen que, a pesar de las disputas en torno a los contenidos de la Constitución, esta preserva su autoridad porque las personas creen en la posibilidad de persuadir a otros - en última instancia a la Corte - de que adopten sus perspectivas sobre el significado de la Constitución.

La forma en que Post y Siegel (2013) describen la manera en que ocurren esas disputas es muy ilustrativa:

La premisa del constitucionalismo democrático es que la autoridad de la Constitución depende de su legitimidad democrática, de su capacidad para inspirar a los estadounidenses a reconocerla como su Constitución. Esta creencia está sostenida en tradiciones de compromisos populares que facultan a los ciudadanos a presentar reclamos referidos al significado de la Constitución y a oponerse a su gobierno (mediante la creación de normas constitucionales, la política electoral y las instituciones de la sociedad civil) cuando consideran que no respeta la Constitución. Los funcionarios del gobierno, a su vez, resisten y responden a estos reclamos ciudadanos. El significado de nuestra Constitución ha sido históricamente configurado por esos complejos patrones de intercambio (p. 44-45).

Los autores expresan que la posibilidad que se da en las discusiones ante los tribunales constitucionales, a las que pueden recurrir diversos actores de la sociedad, permite perseverar en la autoridad y legitimidad de la Constitución, además de afianzar una relación de reconocimiento de los ciudadanos hacia su Carta Fundamental. Respecto de ese reconocimiento, afirman que "conforme al constitucionalismo democrático, la decisión judicial está incrustada en un ordenamiento constitucional que invita con regularidad a un intercambio entre 
funcionarios y ciudadanos sobre cuestiones relativas al significado constitucional" (Post y Siegel, 2013, p. 51).

Podría decirse que esta cuestión resulta aplicable a toda discusión constitucional y no solo a lo realizado en la Sentencia T-025. Aunque esto puede ser cierto, se quieren poner de presente varias consideraciones que hacen que el debate constitucional que dio pie al mencionado fallo, y su posterior seguimiento, sean de especial interés en este caso.

En primer lugar, la situación de vulneración de derechos en forma generalizada y sistemática de la población desplazada cuestionaba la supremacía y vinculatoriedad misma de la Constitución. En este sentido, la discusión en torno a los esfuerzos gubernamentales y legislativos para atender a los desplazados, junto a las demandas que esta población realizaba a través de acciones de tutela tienen las características propias de ese diálogo constitucional que, precisamente, Post y Siegel señalan como refuerzos de la supremacía constitucional en un contexto de su desconocimiento flagrante. Tanto población desplazada como entidades estatales buscaban que del mandato vinculante de la Constitución se concluyera en la protección de sus derechos o que se verificara que no había vulneración alguna de los mismos.

En segundo lugar, los mecanismos creados para garantizar el cumplimiento de la sentencia T-025 de 2004, es decir, autos de seguimiento, Sala Especial de Seguimiento y audiencias con participación del Estado y organizaciones de la sociedad civil, permiten ese esfuerzo dialógico y el reconocimiento de la Constitución, propios del constitucionalismo democrático. ${ }^{1}$

1 Las audiencias públicas que convoca la Sala Especial de Seguimiento a la sentencia T-025 de 2004 de la Corte Constitucional cuentan con la participación de representantes de las instituciones estatales con competencias en la atención a 
Vale la pena decir que estos mecanismos mencionados no están presentes en todo pronunciamiento de constitucionalidad que realiza la Corte. Esta confluencia de actores contribuye no solo a establecer ese diálogo, sino además a que sectores académicos y sociales con posturas diversas y relevantes influyan en las decisiones del tribunal constitucional y en las medidas que se adopten. ${ }^{2}$

En tercer término, la declaratoria del estado de cosas inconstitucional se presenta como la muestra más clara de ese afán de los tribunales constitucionales por preservar la autoridad de la Constitución. Esto guarda relación con el papel que desempeñan los jueces constitucionales en el Estado social y democrático de derecho.

Rosanvallón (2010) ofrece una explicación a partir de los fundamentos, sobre la legitimidad de las cortes constitucionales en la actualidad: "Las cortes constitucionales tienen por función enmarcar la producción legislativa sometiéndola a una fortalecida obligación de generalidad con relación a la expresión mayoritaria. Su legitimidad está vinculada con el carácter reflexivo de su intervención" (p.32).

la población desplazada, así como de organizaciones sociales, de víctimas y grupos académicos que se dedican al tema.

2 Ha sido explícito el papel que desempeña la Comisión de Seguimiento a la Política Pública sobre Desplazamiento Forzado en la formulación de recomendaciones que ha tenido la Corte para efectuar seguimiento e impartir nuevas órdenes en el marco de la Sala de Seguimiento. La integración heterogénea de esta comisión también resulta un aporte importante en el estudio interdisciplinario del fenómeno del desplazamiento forzado en Colombia y en brindar respuestas al respecto. Han hecho parte de la Comisión de Seguimiento Eduardo Cifuentes Muñoz, Luis Jorge Garay Salamanca, Monseñor Héctor Fabio Henao, Rodrigo Uprimny Yepes, Patricia Lara Salive, Marco Romero Silva, Pedro Santana Rodríguez, Fanny Uribe Idárraga, Olga Amparo Sánchez, José Fernando Isaza, Jorge Enrique Rojas, Luis Evelis Andrade, Rosalba Castillo y Orlando Fals Borda (q.e.p.d.). 
Ese carácter reflexivo y contramayoritario de la actividad de las cortes constitucionales, guarda una relación estrecha con la incidencia de los ciudadanos en la acción de sus gobernantes. Según Rosanvallón (2010) "el desarrollo de esas cortes también puede ser considerado como un instrumento de reducción del margen de maniobra de los gobernantes y, por lo tanto, como una forma de aumento del control social sobre los representantes"(p. 193).

Es en estos términos que podemos caracterizar lo que algunos académicos han denominado el "papel político de la Corte Constitucional” (Londoño Toro y Pizarro Nevado, 2005, p. 20), con ocasión de la sentencia T-025 de 2004. A partir de lo esbozado sobre constitucionalismo democrático y el papel de la Corte en nuestro Estado constitucional y democrático de derecho, su papel político consiste en abrir espacios de diálogo y discusión en los que actores institucionales y de la sociedad civil discuten el contenido de las provisiones constitucionales, con lo cual se afianza la pretensión de autoridad de nuestra Constitución y, a su vez, se abre la posibilidad de que ciudadanos en especial situación de vulnerabilidad en sus derechos fundamentales, como lo son las personas en situación de desplazamiento, permitan ejercer control sobre las entidades implicadas, acotar y dirigir su acción.

Todos estos mecanismos mencionados y la correspondencia con ese "papel político" de la Corte fueron de utilidad para identificar la problemática probatoria que enfrentaban las víctimas de desplazamiento forzado y para establecer un punto de partida para la superación de tal problemática. 


\section{El debate probatorio de la población desplazada en las decisiones de la Corte Constitucional}

La Corte, al abordar los problemas de la población desplazada para acreditar la situación o calidad de desplazado, tomó especial consideración por las circunstancias a las que se enfrentaba esta población para ver reconocidos los servicios asistenciales del Estado y la garantía de sus derechos. Por este motivo, uno de los puntos más álgidos de esta situación ha sido la materia probatoria, toda vez que la legislación no se encontraba en capacidad de asimilar la situación producto de este suceso y la jurisprudencia constitucional apuntó a la "flexibilización probatoria".

La jurisprudencia tuvo que ocuparse de esta temática según los principios constitucionales, apartándose en ocasiones de las posturas legislativas y estableciendo como criterios dos elementos principales: "la coacción que hace necesario el traslado y la permanencia dentro de las fronteras de la propia nación. Si estas dos condiciones se dan [...] no hay la menor duda de que se está ante un problema de desplazados" (CConst., T-227/1997, A. Martínez Caballero).

De esta manera, la Corte, desde las primeras revisiones de esta materia, demostró el entendimiento que se le debía dar a la situación de desplazamiento trayendo, desde el ámbito internacional, directrices que armonizaran la posición del Estado como garante y protector de los derechos fundamentales consagrados constitucionalmente para las personas, sin que se vieran afectadas por exigencias de la legislación que desconocían al desplazamiento forzado como una situación de hecho (CConst., T-227/1997, A. Martínez Caballero).

Tenemos entonces que, incluso antes de la expedición de la sentencia T-025, el análisis que realizó la Corte de la situación del desplazamiento forzado como una situación de hecho 
contó con aportes relevantes de organizaciones no gubernamentales con experiencia en la materia pues de acuerdo con:

[...] los Principios Rectores de los Desplazados Internos, la ley 387 de 1997, la jurisprudencia de esta Corporación y los conceptos rendidos por codHes y la Comisión Colombiana de Juristas, es claro que el desplazamiento forzado por ser una situación de hecho no necesita, como requisito indispensable para adquirir la condición de desplazado ser declarado por ninguna entidad ni pública ni privada para configurarse.

La comprensión del desplazamiento realizada por la Corte, con la contribución de organizaciones como codHes y la Comisión Colombiana de Juristas, ayudó a superar esas barreras que enfrentaban las víctimas a la hora de reclamar ante las agencias gubernamentales las prestaciones y derechos que la legislación establecía a favor de la población desplazada, siendo un punto de partida para relevar de deberes probatorios de su condición a esta población. (CConst., T-1365/2000, F. Morón Díaz).

Los criterios fijados por la Corte no solo iban dirigidos a las agencias gubernamentales con competencias en la atención de la población desplazada, sino a los funcionarios judiciales que conocían de las acciones de tutela que promovían organizaciones de desplazados y personas en forma individual. Así, la Corte determinó que la existencia del acervo probatorio era una exigencia demasiado alta para las circunstancias que acarreaba esta situación de hecho y, por tanto, recae en el juzgador la valoración adecuada de las medidas o circunstancias que permitieran desestimar la necesidad de probar cierta circunstancia. 
Todos estos criterios apuntaban a la presunción de buena fe y a la inversión de la carga de la prueba en materia de acreditar o no la calidad de desplazado, como respuestas jurídicas que materializaran la protección de los derechos fundamentales de la población desplazada. Por lo anterior, le corresponde a las agencias estatales comprobar que la persona que se reputa desplazada no tiene en realidad esa condición y, en consecuencia, ya no sea beneficiaria de la oferta estatal. En el mismo sentido se ha planteado que la calidad de desplazado podrá perderse en la medida que se compruebe que los hechos declarados no son ciertos, afirmación que sí requerirá acervo probatorio que otorgue en grado de certeza la evidencia de tal aseveración.

$\mathrm{Al}$ respecto, señaló la Corte:

Al presumirse la buena fe, se invierte la carga de la prueba $y$, por ende, son las autoridades las que deben probar plenamente que la persona respectiva no tiene la calidad de desplazado. Por lo tanto, es a quien desea contradecir la afirmación a quien corresponde probar la no ocurrencia del hecho. El no conocimiento de la ocurrencia del hecho por autoridad gubernamental alguna no es prueba de su no ocurrencia. Es apenas prueba de la inmanejable dimensión del problema que hace que en muchas ocasiones las entidades gubernamentales sean desconocedoras del mismo. En muchas ocasiones las causas del desplazamiento son silenciosas y casi imperceptibles para la persona que no está siendo víctima de este delito. Frente a este tipo de situaciones es inminente la necesidad de la presunción de buena fe si se le pretende dar protección al desplazado (CConst., T-327/2001, M. G. Monroy Cabra). 
Ya con posterioridad a la expedición de la T-025, cuyo cumplimiento implicaba grandes esfuerzos de tipo presupuestal, administrativo e institucional, la Corte decidió crear la Sala de Seguimiento en abril de 2009, encargada de verificar el cumplimiento a la sentencia para lograr la superación del estado de cosas inconstitucional en materia de desplazamiento. En el cumplimiento de esta función, esta Sala sería la encargada de pronunciarse mediante autos y la realización de audiencias públicas con los diferentes actores.

A través de varios autos, la Corte, al tiempo que identifica las dificultades en materia probatoria para acreditar la condición de las personas víctimas de desplazamiento forzado, formula órdenes a las autoridades competentes para que se abstengan de interponer requisitos formales o especiales como exigencias probatorias a la población desplazada para acceder a la ayuda humanitaria.

En primer lugar, reconoció un problema de subregistro de la población desplazada y vio la necesidad de que los desplazados que han sido rechazados sean debidamente registrados, ordenando además al director de Acción Social "que realice una presentación del proyecto de decisiones que planean adoptar para superar los problemas de subregistro, teniendo de presente que el ciudadano no tiene la carga de demostrar su condición de desplazado"(CConst., Auto 011/2009, M.J. Cepeda Espinosa).

Esta cuestión continuó siendo objeto de seguimiento por la Sala Especial de Seguimiento e incluso en 2011 la Sala Especial solicitaba informes a Acción Social sobre la adopción de decisiones y protocolos que dieran cuenta de que no se estaban presentando rechazos de inscripción de las víctimas en el Registro Único de Población Desplazada (RUPD) por cuenta 
de exigencias probatorias o requisitos no contemplados en la Ley (CConst., Auto 219/2011, L. E. Vargas Silva).

La Corte reiteró que el ciudadano desplazado tiene entre sus derechos básicos ser reconocido, tanto él como su grupo familiar, como víctima del desplazamiento y, por ende, si no se encuentra en la capacidad de probarlo, es deber del Estado inscribirle en el registro. A pesar de esto, la Corte establece que desde que el Registro Único de Victimas empezó a ser administrado por la Unidad de Víctimas se han recibido informes en los cuales se denuncia un grave retroceso en materia de atención y protección de las víctimas respecto del registro, y el análisis de la Sala Especial se ha centrado en constatar que la Unidad de Víctimas esté aplicando en forma efectiva,y no solo retórica, los lineamientos probatorios y de valoración favorables a las declaraciones de las víctimas conforme con la jurisprudencia constitucional (CConst., Auto 052/2013, L. E. Vargas Silva).

Posteriormente la Corte requirió a las autoridades competentes para que no exigieran requisitos no contemplados en la ley para acceder a los beneficios establecidos para la población desplazada, como declaraciones judiciales sobre la integración de la jefatura familiar. De acuerdo con la Corte, este comportamiento no solo cuestionaba la situación de hecho que significa el desplazamiento, sino que además vulnera el derecho al registro del cual es titular la población desplazada y consecuentemente el derecho al mínimo vital por la negativa a otorgar las ayudas humanitarias de emergencia (CConst., Auto 099/2013, L. E. Vargas Silva).

Por lo anterior, es factible concluir que la incorporación al ordenamiento de remedios adoptados en un principio desde la jurisprudencia permitió evitar una violación mayor a la obligación del Estado de proteger efectivamente las garantías 
y derechos previstos por el ordenamiento, de acuerdo con los criterios constitucionales de justicia material sobre la base del principio constitucional de buena fe e interpretaciones judiciales que no vayan en contra de los preceptos constitucionales. Además, surgen como respuesta oportuna a los retrocesos que el mismo proceso de seguimiento a cargo de la Sala Especial va identificando en materia de registro de las víctimas y su inclusión en los registros.

Estos instrumentos establecidos jurisprudencialmente inciden de forma permanente en el diseño y ejecución de la política pública de atención a las víctimas del conflicto armado, como se verá en el siguiente apartado.

\section{La sentencia T-025 de 2004.} Antecedente de la Ley de Víctimas

La cuestión, en materia probatoria, de acreditar la calidad de víctima ante las entidades estatales y proceder a su inscripción en los registros con el fin de acceder a la oferta estatal tiene una importante relación con la nueva institucionalidad que se ha creado con la Ley 1448 de 2011, también denominada Ley de Víctimas.

Esta ley ha incorporado en forma explícita varias de las interpretaciones jurídicas realizadas por la Corte que presentamos en la sección anterior y que contaron con la incidencia y participación de actores sociales relevantes, como la academia y las organizaciones de víctimas. Precisamente, el principio de buena fe y la flexibilización probatoria son dos de los instrumentos que ofrece la ley para facilitar a las víctimas su inclusión en el Registro Único de Víctimas para recibir el reconocimiento y las garantías propias de los derechos a la verdad, justicia y reparación. 
Para evidenciar esto de forma concreta, un ejemplo muy diciente es el desarrollo que la jurisprudencia constitucional ha hecho en materia de restitución de tierras, sobre el principio de buena fe para tener en cuenta las declaraciones de las víctimas y los instrumentos jurídicos asociados a la flexibilización probatoria.

En primer lugar, el principio de buena fe está incluido en la ley en el sentido que se presume la buena fe de las víctimas, estas pueden probar el daño sufrido sumariamente y esta prueba será suficiente para que opere la inversión de la carga de la prueba, tal y como lo estableció la Corte Constitucional (CConst., C-253A/2012, G. E. Mendoza Martelo). A su vez, las autoridades administrativas deben establecer reglas de prueba que faciliten a las víctimas la demostración del daño. Sin embargo, esto no descarta los problemas que ha identificado la Sala de Seguimiento en la implementación de esta norma por parte de la Unidad de Víctimas que fueron referenciados anteriormente.

En este sentido, esta flexibilización probatoria se materializa no solo en relevar a las víctimas de la carga de la prueba, sino en la inversión de la carga de la prueba en los procedimientos administrativos y judiciales diseñados para la garantía de los derechos de las víctimas y en las presunciones establecidas en la ley, específicamente en el proceso de restitución de tierras. Así, el artículo 78 de la Ley 1448 establece que bastará la prueba sumaria de la propiedad, posesión u ocupación o la prueba sumaria del despojo para que se traslade la carga de la prueba a quienes se opongan a la pretensión de restitución de las víctimas.

A su vez, las presunciones de despojo del artículo 77 de la Ley 1448 facilitan que las víctimas den cuenta del mismo y se le encargue a los opositores de la restitución solicitada probar 
que no se encuentran en los supuestos de esas presunciones o desvirtuarlas cuando la ley lo admita.

He aquí uno de los avances más dicientes en materia legislativa en lo que al concepto de flexibilización probatoria se refiere, toda vez que no se releva únicamente a las víctimas de agotar de manera rigurosa el ordenamiento, sino que se le otorga al juez amplias facultades en esta materia, puesto que "[ $\mathrm{t}]$ an pronto el juez o magistrado llegue al convencimiento respecto de la situación litigiosa, podrá proferir el fallo sin necesidad de decretar o practicar las pruebas solicitadas" (L. 1448/2011, art. 89), haciendo aplicable el concepto de flexibilidad probatoria no solo a las víctimas, sino a la administración de justicia.

Quiere ponerse de presente entonces que, atendiendo a las circunstancias del desplazamiento forzado y del conflicto armado, estas herramientas que pueden tener un contenido técnico jurídico muy alto se traducen en una herramienta cercana a las víctimas para ver garantizado su derecho a la reparación, por lo menos en el componente de restitución de tierras.

\section{Conclusiones}

En primera medida, la Corte Constitucional, por medio de la Sala Especial de Seguimiento a la Sentencia T-025 de 2004, sus autos de seguimiento y las audiencias públicas guarda correspondencia con las teorías sobre constitucionalismo democrático de Robert Post y Reva Siegel. Esto significa que la Corte, en búsqueda de garantizar la vinculatoriedad y la autoridad de la Constitución frente a las diversas problemáticas asociadas al desplazamiento forzado, comprende que los debates sobre el contenido de las disposiciones constitucionales deben contar con la participación tanto de las agencias gubernamentales y otros órganos estatales, como de sectores 
de la sociedad civil como organizaciones académicas, organizaciones de derechos humanos, de víctimas o de aquellas que agrupen población desplazada.

Las audiencias y los autos de seguimiento, que cuentan con estos aportes diversos se traducen en que la Corte desempeña un papel político en el sentido que, por conducto suyo, los ciudadanos influyen, inciden y ejercen control sobre las entidades públicas con competencias en la atención de la población desplazada y participan en la construcción y adopción de las medidas que se consideren adecuadas para mejorar la situación.

Este comportamiento, acorde con el constitucionalismo democrático, le permitió a la Corte resaltar el problema que enfrentaba la población desplazada respecto de las exigencias probatorias para acreditar su condición de desplazada y acceder a la oferta estatal de servicios establecidos legalmente para superar su situación de desplazamiento. Del mismo modo, el seguimiento permanente de la Sala Especial se ha desarrollado, por lo menos en los últimos dos años, en forma concomitante a las transformaciones institucionales con ocasión de la expedición de la Ley de Víctimas y ha ejercido un seguimiento pertinente y de advertencia ante posibles retrocesos que esté trayendo esta transformación institucional en materia probatoria. La Sala Especial de Seguimiento a la sentencia T-025 guarda entonces una relación paralela con la Ley de Víctimas, pero otra relación importante es que sus decisiones han sido importante antecedente en lo que a flexibilización probatoria se refiere.

Se mostró entonces cómo, antes de la sentencia T-025 de 2004, la jurisprudencia de la Corte ya había perfilado el tratamiento que debían recibir las personas desplazadas por parte de las autoridades respecto de la valoración de las decla- 
raciones de las víctimas y su inscripción en los registros. En esta jurisprudencia y en los posteriores autos de seguimiento se afianzó esta línea, esbozando el principio de buena fe en favor de las víctimas y figuras jurídicas como la inversión de la carga de la prueba y presunciones que hoy en día son un aspecto central e innovador de la Ley 1448 de 2011. Es así como la Sentencia T-025 de 2004 y sus autos de seguimiento constituyen un antecedente relevante en el diseño institucional y legal de la Ley de Víctimas, contribuyendo a una materialización de los derechos de las víctimas del conflicto en general y de la población desplazada en particular.

\section{Referencias bibliográficas}

Londoño Toro. B. \&Pizarro Nevado, R. (2005). Derechos humanos de la población desplazada en Colombia evaluación de sus mecanismos de protección. Bogotá: Centro Editorial Universidad del Rosario.

Parra Quijano, J. (1998). Manual de Derecho Probatorio. Bogotá: Librería del Profesional.

Post, R., \& Siegel, R. (2013). Constitucionalismo democrático: Por una reconciliación entre Constitución y pueblo. Buenos Aires: Siglo Veintiuno.

Rosanvallon, P. (2010). La legitimidad democrática. Imparcialidad, reflexividad y proximidad. Madrid: Paidós.

\section{Jurisprudencia y legislación}

Cepeda Espinosa,M.J. (22 de enero de 2004). Sentencia T-025/04. Bogotá: Corte Constitucional. Recuperado de http://www. corteconstitucional.gov.co/relatoria/2004/t-025-04.htm

Cepeda Espinosa, M. J. (26 de enero de 2009). Auto 011/09. Bogotá: Corte Constitucional. Recuperado de http:// www.corteconstitucional.gov.co/T-025-04/AUTOS\%20 
2009/118.\%20Auto\%20del\%2026-01-2009.\%20Auto\%20 011\%20Habeas\%20Data.pdf

Cifuentes Muñoz, E. Sentencia SU1150/00. Bogotá: Corte Constitucional. Recuperado de http://www.acnur.org/t3/filead$\mathrm{min} /$ scripts/doc.php?file=biblioteca/pdf/1318

COLOMBIA. Congreso de la Republica (10 de junio de 2011). Ley 1448 de 2011. Por la cual se dictan medidas de atención, asistencia y reparación integral a las víctimas del conflicto armado interno y se dictan otras disposiciones.

Martínez Caballero, A. (5 de mayo de 1997). Sentencia T-227/97. Bogotá: Corte Constitucional. Recuperado de http://www. corteconstitucional.gov.co/relatoria/1997/T-227-97.htm

Mendoza Martelo, G. E. (29 de Marzo de 2012). Sentencia $C$ 253A/12. Bogotá: Corte Constitucional. Recuperado de http://www.corteconstitucional.gov.co/relatoria/2012/c253a-12.htm

Monroy Cabra,M. G. (26 de marzo de 2001). Sentencia T-327/01. Bogotá: Corte Constitucional. Recuperado de http://www. corteconstitucional.gov.co/relatoria/2001/t-327-01.htm

Morón Díaz, F. (11 de octubre de 2000). Sentencia T-1365/00. Bogotá: Corte Constitucional. Recuperado de http://www. corteconstitucional.gov.co/relatoria/2000/T-1365-00.htm

Vargas Silva, L.E. (13 de octubre de 2011). Auto 219/11. Bogotá: Corte Constitucional. Recuperado de http://www.corteconstitucional.gov.co/relatoria/autos/2011/a219-11.htm

Vargas Silva, L. E. (19 de marzo de 2013). Auto 052/13. Bogotá: Corte Constitucional. Recuperado de http://www. corteconstitucional.gov.co/T-025-04/AUTOS\%20 2013/010.\%20Auto\%20052\%20de\%2019-03-2013.\%20 Decreto\%20de\%20pruebas.pdf 
Vargas Silva, L. E. (21 de mayo de 2013). Auto 099/13. Bogotá: Corte Constitucional. Recuperado de http://www.corteconstitucional.gov.co/relatoria/autos/2013/a099-13.HTM 


\title{
La justicia transicional de la Ley 1448 de 2011, ¿beneficio o impunidad? Aplicación de la Ley de Víctimas y Restitución de Tierras en el acompañamiento y asistencia técnica dado a los campesinos por parte del Estado en el departamento del Meta, en los municipios de Puerto Gaitán, San Martín y Cubarral
}

\author{
Diana Judith Arenas Jiménez \\ Gustavo Adolfo Basto Forero \\ Nathalia Andrea Marín Hernández \\ Lina María Mejía Torres*
}

\section{Resumen}

La Ley 1448 de 2011 afirma: "siempre que sea posible se intentará devolver a la víctima a la situación anterior al despojo de su predio", pero una vez restablecido el derecho no da a

\footnotetext{
* Universidad Santo Tomás Villavicencio. Línea de Investigación de Derechos Humanos, Semillero Fray Antonio de Montesinos. Estudiantes de octavo semestre de la Facultad de Derecho. Correo electrónico: dianaarenas@usantotomás.edu.co, gustavobasto@usantotomas.edu.co,nathaliamarinh@usantotomas.edu.co, linamejia@usantotomas.edu.co
} 
entender el alcance que es posible tener en cuanto al disfrute, la reintegración a su empleo, financiación y el estado del nuevo bien en dado caso.

Analizando lo anterior y teniendo en cuenta que la Unidad de Restitución de Tierras junto a jueces y Magistrados Especializados en Restitución son los acompañantes en dicha etapa post-fallo, según lo afirmado tanto por la Ley de Víctimas, cuanto por los decretos reglamentarios y el Plan Nacional para la Atención y Reparación Integral de las Víctimas, buscamos responder con esta investigación si la justicia transicional guarda cierta ambigüedad en el tema post-fallo, especialmente en el posible retorno a los predios, la garantía que se debe mantener en cabeza del Estado para que a las víctimas se garantice la permanencia en los terrenos objeto de restitución y el acompañamiento técnico que se les brinda en los municipios objeto de esta investigación.

\section{Introducción}

El presente trabajo es la documentación de un proyecto de investigación en curso, mediante el cual se busca dar respuesta a las diversas preguntas que surgen a partir de la aplicación de la Ley 1448 de 2011, Ley de Víctimas y Restitución de Tierras, como mecanismo transicional, cuyo objetivo fundamental es contrarrestar las consecuencias producidas por el conflicto armado y el despojo de las tierras.

Dentro el contenido de la ley en mención se observa que al momento de querer resaltar la reparación integral específicamente en el tema de restitución de los predios, la aludida normatividad se limita a establecer quiénes son víctimas, cuáles son sus derechos, cómo resarcir el daño por el cual fueron afectados y su articulado, entre otras cosas, enuncia quiénes se acogen a la referida ley y quiénes pueden acceder a la misma, 
además de otros. Es por ello que en nuestro criterio se evidencia un limbo jurídico respecto del tema de la reparación integral a las víctimas.

E1 Decreto Reglamentario 4829 de 2011, el cual delimita el Capítulo III (Disposiciones Generales) del Título IV de la Ley 1448 de 2011 con relación a la restitución de tierras, da unas directrices generales que aun así no llegan al fondo de la situación, pues solo mencionan un análisis al caso específico de restitución individual y sus posibles soluciones, sin embargo, no da a entender si se aplicarán todas o algunas de las medidas o lineamientos, mencionados en principio. Solamente en el Plan Nacional para la Atención y Reparación Integral de las Víctimas, anexo del Consejo Nacional de Política Económica y Social (conPEs 3726 de 2012), se hace alusión al tipo de acompañamiento que se brindará, e integra de algún modo en su totalidad el tema de restitución.

Entendido, entonces, que la normatividad no es completamente clara, toda vez que remite a diversos documentos, genera vacíos y se obtiene como consecuencia la imposibilidad de dar cumplimiento a la ley (lo cual con posterioridad la jurisprudencia y la doctrina tendrán que llegar a solucionar), este proyecto de investigación busca entonces identificar algunas de las lagunas jurídicas generadas por la situación anteriormente descrita, con el fin de evitar la impunidad que inició en el momento del despojo de tierras. Teniendo esto en cuenta, se busca proponer estrategias claras y precisas que sirvan de horizonte en los fallos de los jueces de restitución de tierras, identificando el acompañamiento que se debe dar en conjunto con la Unidad de Tierras, para efectos de la protección integral de las víctimas, haciendo útiles los fines de esta investigación. 


\section{Justificación}

El grupo de investigación Fray Antonio de Montesinos, Línea Derechos Humanos, perteneciente a la Facultad de Derecho de la Universidad Santo Tomás investigará respecto a cuál es el plan de acompañamiento, cuáles las rutas de reparación integral y la asistencia técnica a las víctimas, como consecuencia se observará la participación de las diferentes instituciones, tanto del orden central como descentralizado, y demás entidades encargadas, identificando hasta qué momento se ha hecho el acompañamiento y la eficacia que tiene la implementación de la Ley de víctimas y restitución de tierras.

Para dar respuesta a lo anterior, se han seguido dentro de la investigación los objetivos específicos planteados, llevando hasta el momento en ejecución el objetivo de determinar si dentro del Plan Nacional de Atención y Reparación a Víctimas existe un acompañamiento y reparación integral posterior al agotamiento de la ruta y procedimiento para la restitución, es decir, se han identificado en primera medida las acciones de la implementación de la Ley 1448 de 2011 mediante recolección y análisis de información (documentos, derechos de petición, líneas jurisprudenciales, foros, conferencias, capacitaciones y audiencias), dando paso al análisis no solo de la ley sino de los planes nacionales de atención y reparación integral a las víctimas posteriores al agotamiento de la ruta y procedimiento para la restitución, lo cual se está ejecutando a través de la aplicación de instrumentos de recolección de información a los participantes de la investigación.

De igual forma, a través de lo anterior, posteriormente se analizarán las rutas de atención existentes para evaluar que dentro de las mismas se tengan en cuenta los mecanismos jurídicos y participativos administrativos o judiciales que reconozcan e implementen la efectividad del derecho a las 
personas que fueron afectadas por el despojo de sus tierras, así como otros mecanismos para su protección y posterior subsistencia.

\section{Palabras clave}

Restitución de tierras, implementación, acompañamiento, departamento del Meta, mecanismos.

\section{Planteamiento del tema y pregunta}

La restitución de tierras es un tema de vital importancia en Colombia. Se estima que existen cerca de 5,9 millones de desplazados reconocidos en el RUV ${ }^{1}$ a nivel nacional, siendo el Meta uno de los departamentos con mayor incidencia con 306.097 personas desplazadas. Según la tendencia del RUV se creen que son cerca de 7.169 casos de posible abandono y despojo de tierras como consecuencia del conflicto armado y como antecedente histórico encontramos que dicha causa tuvo su inicio en este país con la usurpación de tierras a los campesinos y los múltiples intentos de reformas agrarias en nuestra legislación, lo que ha acarreado un vacío en cuanto a la protección de la tierra, la cual se ha venido tratando a partir del marco de la Constitución como Estado social de derecho que es el colombiano.

Con la sentencia T-025 de 2004, la Corte Constitucional declaró el estado de cosas inconstitucionales, en la cual se demuestra lo siguiente:

[...] i) la proliferación de acciones de tutela como única alternativa ante la desatención oficial del derecho de justimación. 
cia infringido; ii) la conversión de la acción de tutela en un trámite más para la atención del derecho; y iii) la ausencia de políticas públicas y planes estatales orientados a superar la situación (Plazas Vega, 2012, 6).

Lo anterior plantea la necesidad de intervenir de una forma rápida y oportuna para darle una solución al conflicto suscitado, pero es solo a partir del año 2010, con el Auto de Seguimiento número 383, que se dictan las directrices que se deben tener en cuenta en el tema de restitución, es decir, seis (6) años después de que se conoce de manera profunda la gravedad de la problemática del desplazamiento forzado que afronta nuestro país. En lo que respecta al departamento del Meta, según dicho Auto, la coordinación de las distintas entidades se empieza a hacer en ese mismo año, empero, las caracterizaciones de los municipios y la realización de actividades conjuntas de diversos organismos estatales no se implementan sino hasta junio de 2011 (Defensoría del Pueblo, 2012, p. 166-168), demostrando la lentitud del sistema nacional para adoptar medidas eficientes y diligentes.

En el marco de la Ley 1448 de 2011 (por la cual se legisla de nuevo para proteger la tierra campesina), con la realización de un balance a nivel local y con las cifras mencionadas en principio, esta investigación busca realizar un seguimiento no solo de la implementación de esta ley en cuanto a la restitución, sino a los mecanismos que dan paso para hacer efectiva dicha protección y dicho acompañamiento una vez restituido el bien inmueble, y que no solo haya satisfacción en cuanto a su entrega material, sino que exista la posibilidad de garantías para la protección de los derechos a la vida e integridad personal de las víctimas posteriormente a la restitución. 
Asimismo, se busca analizar la existencia de las cargas que obtendrá la persona que accede a esta ley para su desarrollo en la vida del campo, puesto que ingresarán a este predio sin las condiciones mínimas para su sustento, pues la restitución consiste en el desarrollo de programas productivos para el campesino y no solo el retorno de su derecho.

El siguiente gráfico muestra la organización dada para la ruta de reparación diseñada por el Plan Nacional de Atención y Reparación Integral a Víctimas (PNARIV), dentro de la documentación dada por el Departamento de Planeación Nacional (conpes 3712 de 2012), la cual no demuestra si este acompañamiento, desde un punto de vista de reparación integral, ayuda a la víctima a una adaptación completa.

Es decir, cada forma de reparación no se analiza como un conjunto, sino que, en su lugar, establece las diferentes actividades de los diversos comités seccionales.

$\mathrm{El}$ acto de restituir y retornar no se debe detener con la implementación de medidas y acompañamientos que solo buscan la producción de la tierra, sin entender los diversos cambios y las situaciones en que se pone de nuevo a la población afectada. Regresar a la tierra, deteriorada tanto por el paso de tiempo como por el paso de distintas personas sobre ellas, no asegura que el campesino sea capaz de ponerla en funcionamiento tanto en materia de administración como de cuidados específicos sin tener el conocimiento de lo que ha sucedido con ese predio en los últimos años. 


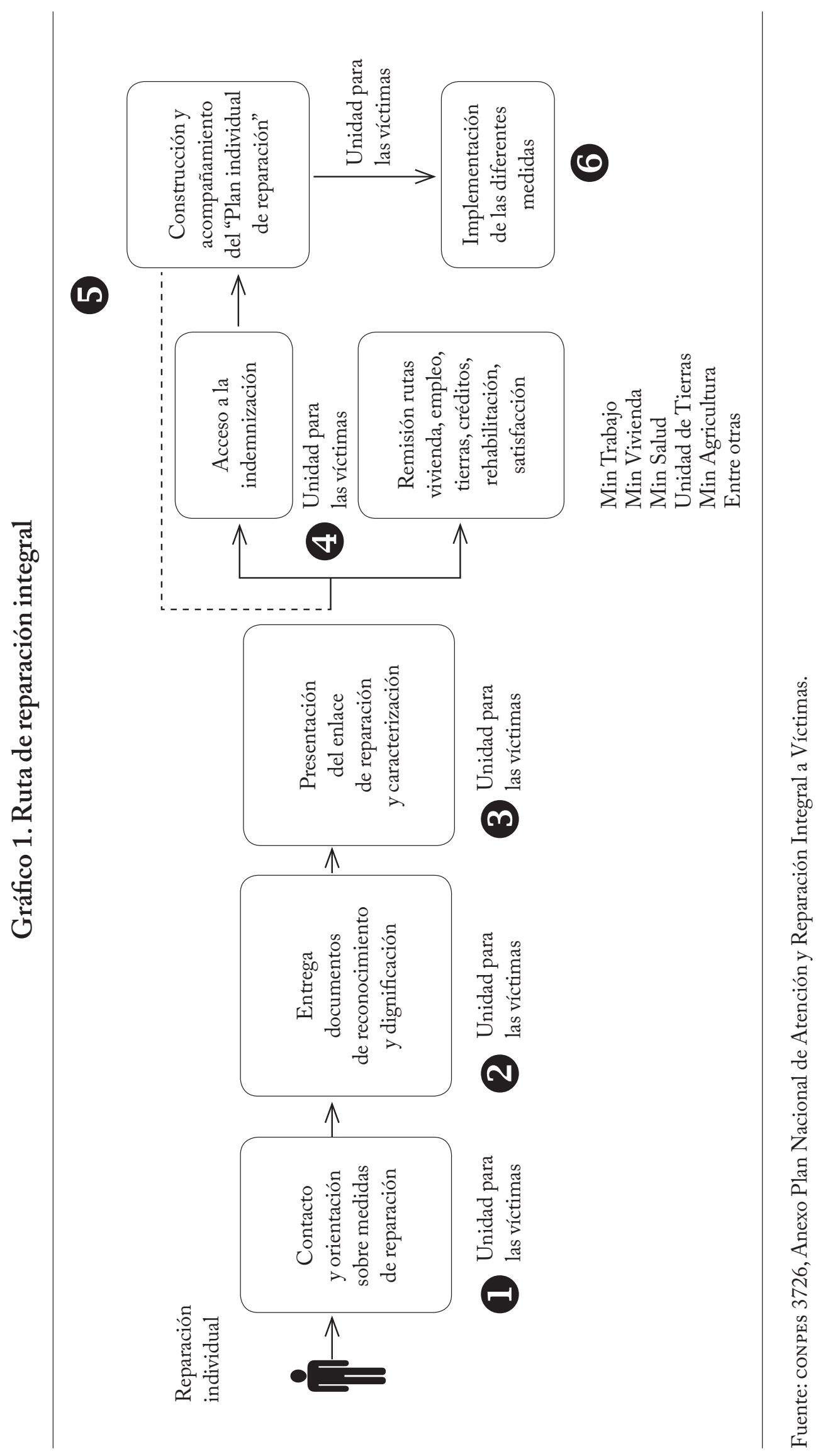




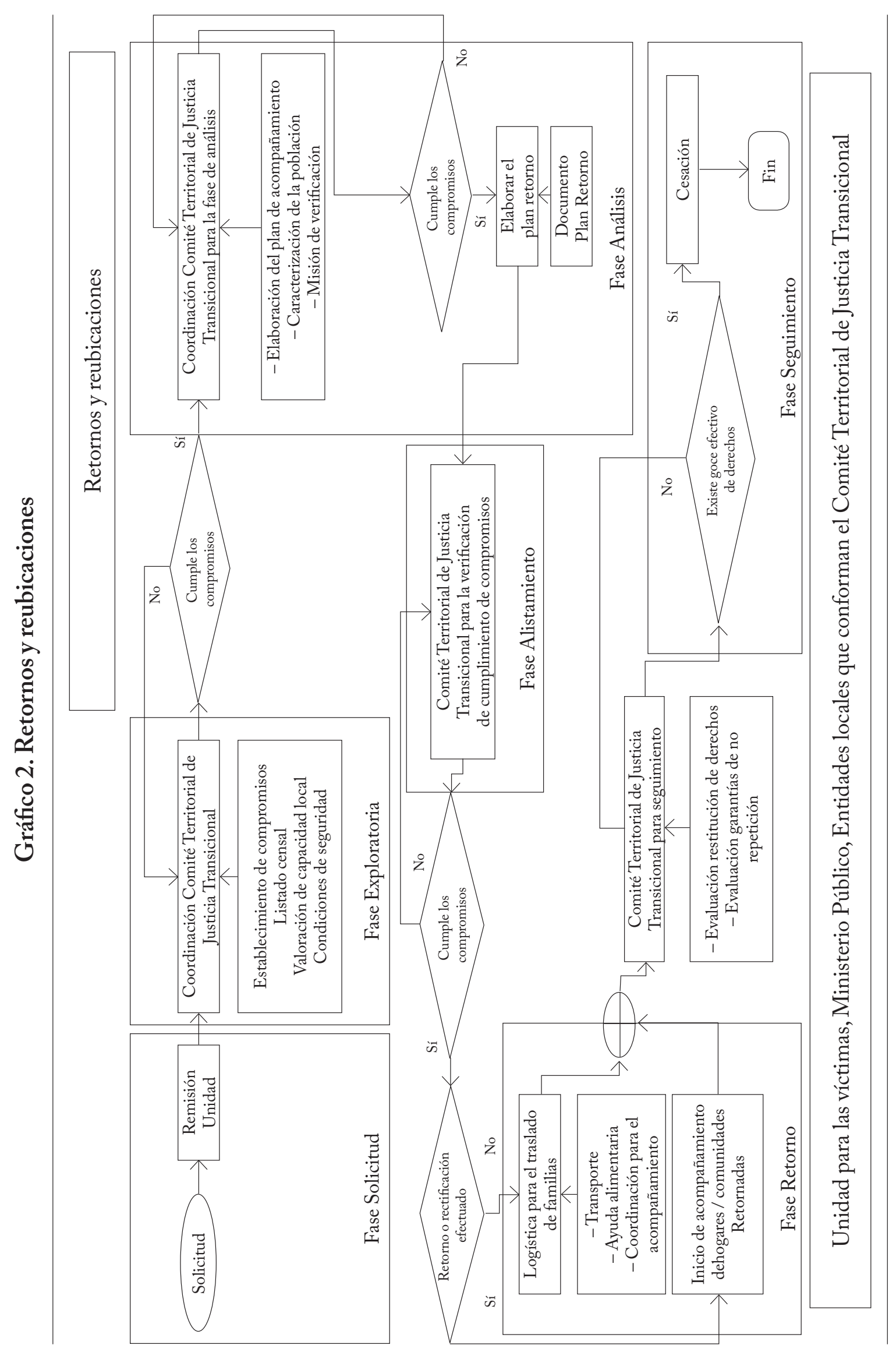


Teniendo en cuenta lo anterior, debemos resaltar que la ley, dentro del marco de la justicia transicional, provee un escenario para la atención, asistencia y reparación a las víctimas del conflicto de las cuales las víctimas de abandono y despojo son solo una parte y la restitución de bienes es solo una de las medidas posibles, sobre la cual a continuación nos vamos a centrar. Por todo lo cual se plantea la pregunta: ¿Cómo se está implementando el proceso de reparación de las víctimas de la violencia a partir de la Ley 1448 de 2011?

\section{Objetivo general}

Revisar cómo se implementa la Ley de Víctimas y Restitución de Tierras (Ley 1448 de 2011) en los municipios de Puerto Gaitán, San Martín y Cubarral en el departamento del Meta.

La escogencia de los municipios se realizó a partir de las condiciones geográficas, las cuales demuestran que para cada uno de ellos el modelo tanto de reparación como de productividad de la tierra dependen de la situación del suelo (la cual ha variado con el paso del tiempo). Lo anterior genera que no sea posible hablar de igualdad de condiciones en todos y cada uno de ellos.

\section{Objetivos específicos}

1. Identificar las acciones específicas que se han implementado con el fin de materializar la Ley 1448 de 2011 en los municipios de Puerto Gaitán, San Martín y Cubarral a través de los Planes de Acción Territorial y el apoyo de la Unidad para la Restitución de Tierras.

2. Determinar si dentro del Plan Nacional de Atención y Reparación Integral a Víctimas existe un acompañamiento y reparación integral posterior al agotamiento de la ruta y procedimiento para la restitución. 
3. Proponer una estrategia alternativa de atención judicial y administrativa del derecho a la tierra teniendo en cuenta las particularidades de los municipios de Puerto Gaitán, San Martín y Cubarral del departamento del Meta.

\section{Desarrollo del planteamiento}

\section{El acceso a la justicia como derecho de las víctimas}

Los derechos que han sido vulnerados a los desplazados deben abordarse con la importancia de derechos fundamentales. Uno de los derechos que debe ser considerado de vital importancia a la hora de la reparación de las víctimas del conflicto armado es el derecho de acceso a la administración de justicia.

El derecho a acceder a la justicia es aquel que permite y exige de los Estados la obligación de protección y atención de las necesidades que se le presentan a las personas en su diario vivir, así como la creación de herramientas e instituciones para que sus asociados tengan la posibilidad de acudir en cualquier situación al sistema judicial para que les sean resueltos sus conflictos y se les garanticen los derechos y principios constitucionales (Fajardo, p. 36, 2009).

La población desplazada debe tener un acceso eficaz a la justicia para que sean respetados los derechos que les están siendo vulnerados y en este caso para que tengan una rápida y apropiada restitución de tierras.

La Corte Constitucional, en sentencia T-958 de 2001, estableció la importancia de las consideraciones especiales para esta población. Las personas víctimas de situaciones 
extremas [...] constituyen el espectro de personas en situación de debilidad manifiesta, aquellas que sufren en mayor medida por razón del desarraigo, destrucción de la base material que sustenta su proyecto de vida así como por la grave afectación del tejido social al cual pertenecen. De ahí que deban ser destinatarios de excepcionales mecanismos de protección pues la capacidad real para realizar su proyecto de vida se ha visto sometido a una reducción incompatible con un estado social de derecho.

Incluso, en esta misma sentencia se resalta: "Han de ser los beneficiarios de mecanismos de atención de situaciones excepcionales (así la excepcionalidad se torne estructural, como ocurre con todos los desplazados pues la naturaleza humana nunca podrá asumirse como algo admisible en el estado social., por hallarse comprometido su mínimo vital [...]”.

\section{Los derechos de las víctimas a la verdad, justicia y reparación}

Respecto a los derechos de las víctimas encontramos los principios de Joinet, los cuales se localizan en el informe final realizado y revisado por $\mathrm{M}$. Joinet, que se fundamenta en tres principios que son la verdad, justicia y reparación para que no se repitan los hechos para evitar futuras violaciones.

En cuanto a los derechos a saber, en el cual hace énfasis el punto 17 del informe, encontramos que no solo los familiares de las víctimas tienen la posibilidad de acceder a estos de manera limitada, sino que existe una posibilidad que va más allá y es el hecho de la existencia de una memoria histórica para así prevenir futuras violaciones.

Así mismo, encontramos otras medidas como la creación de organismos encargados para el manejo y comprobación de 
que acciones como las enunciadas anteriormente sean aplicadas, así como la creación de comisiones no judiciales para la investigación, las cuales se encargan de diversas actividades como velar por la verdad, la credibilidad de los defensores de derechos humanos y testimonios, la garantía de imparcialidad en cuanto a los jueces que lleven los procesos, la publicidad de las imputaciones y la posibilidad de que sea posible responder esta por escrito.

En cuanto a la creación del archivo con relación a las víctimas de derechos humanos, se establece que su función es para evitar el olvido y la posibilidad de repetición de hechos que han causado tal detrimento al Estado y a las personas mismas, así mismo para la producción de la reglamentación de normas y la posibilidad de adaptación a nuevas situaciones o la cooperación con otros países.

Haciendo alusión al derecho a la justicia, este es de obligatorio cumplimiento pero hay que referenciar el hecho que en Colombia para la Ley 1448 de 2011 este implica la posibilidad del acceso a la justicia, por el cual la víctima tenga la oportunidad de poder acceder al aparato judicial, además de garantizar que la persona que ha cometido el delito sea castigada, así mismo, ante la posibilidad de que no exista imparcialidad por parte de los tribunales nacionales, se deberá crear un tribunal especializado como se hizo en otros países (Yugoslavia y Ruanda), o si no, la jurisdicción internacional competente, como sería la Organización de Naciones Unidas.

Encontramos por lo tanto algunas de las medidas adoptadas por este informe para la lucha contra la impunidad, pero hay que entender que para la aplicación de la Ley 1448 del 2011 solo aplican los siguientes aspectos: 
a) La prescripción.

31. La prescripción no puede ser opuesta a los crímenes graves que según el derecho internacional sean considerados crímenes contra la humanidad. En consideración a todas las violaciones, la prescripción no puede correr durante el período donde no existe un recurso eficaz. Asimismo, la prescripción no se puede oponer a las acciones civiles, administrativas o disciplinarias ejercidas por las víctimas. ( $\mathrm{La}$ Administración de la Justicia y los Derechos Humanos de los Detenidos, p. 31, 1997).

En el plano de la reparación el informe (1997) hace especial mención a las personas afectadas por los hechos (víctimas, familiares o personas a cargo), pero agrega que se debe incluir esta en tres campos específicos especialmente para las víctimas individuales:

a) Medidas de restitución (tendentes a que la víctima pueda volver a la situación anterior a la violación);

b) Medidas de indemnización (perjuicio síquico y moral, así como pérdida de una oportunidad, daños materiales, atentados a la reputación y gastos de asistencia jurídica); $y$

c) Medidas de readaptación (atención médica que comprenda la atención psicológica y psiquiátrica).

Para el campo colectivo se refiere a medidas simbólicas (vías, monumentos) en las cuales el Estado deberá reconocer su responsabilidad y por lo tanto no permitirá el olvido de estos sucesos.

Los principios rectores establecidos por la Oficina de Coordinación de Asuntos Humanitarios de las Naciones 
Unidas en 1998 establecen quiénes son los beneficiados, así mismo se declara para los efectos de aplicación de estos principios qué se entiende por población desplazada:

Las personas o grupos de personas que se han visto forzadas u obligadas a escapar o huir de su hogar o de su lugar de residencia habitual, en particular como resultado o para evitar los efectos de un conflicto armado, de situaciones de violencia generalizada, de violaciones de los derechos humanos o de catástrofes naturales o provocadas por el ser humano, y que no han cruzado una frontera estatal internacionalmente reconocida (Principios Rectores de los Desplazamientos Internos, 1998).

La recopilación de estos principios se inicia desde 1992 por diferentes entidades en la que se encuentra el Alto Comisionado de las Naciones Unidas para los Refugiados (ACNUR), organismos regionales, instituciones académicas, organizaciones no gubernamentales y la comunidad jurídica. ${ }^{2}$

Estos principios tienen la finalidad de dar unas garantías a la población flagelada por estos hechos para su protección. Así mismo por ser una recopilación de los diferentes instrumentos busca específicamente: "Reafirman las normas aplicables a los desplazados internos, esclarecer las ambigüedades que puedan existir y tratan de colmar las lagunas identificadas en la compilación y análisis" (Resolución 1997/39). Su división en tres etapas, hace que nos interese más la última (garantías durante el regreso o el asentamiento y la reintegración sustitutorios), la cual es la aplicable al caso específico de la Ley de Víctimas y Restitución de Tierras.

2 Principios Rectores de los Desplazamientos Internos. 
Haciendo mención de lo depositado en este instrumento internacional, se relaciona en cuanto a que su deber principal es garantizar la igualdad tanto en el ámbito internacional como nacional de sus derechos y libertades, de forma que los responsables de estos hechos no queden en la impunidad y no haya una excepción en la aplicación de las leyes penales, principalmente contra los delitos de lesa humanidad, genocidio y guerra.

En el Principio 6 propuesto por OCAH cita que no se justifica el desplazamiento arbitrario, más aún en el literal b del numeral 2: "(b) En situaciones de conflicto armado, a menos que así lo requiera la seguridad de la población civil afectada o razones militares imperativas", que es el caso de estudio específico de esta investigación.

Además de lo ya planteado, el Principio 9 obliga al Estado a la protección efectiva de las personas que dependen o tienen una inclinación por la tierra aún si en ella se presenta conflicto armado (campesinos, indígenas, minorías, entre otros).

Pero lo que realmente interesa de este documento es la Sección V que comenta acerca de los "Principios Relativos al Regreso, el Reasentamiento y la Reintegración”; estos se encuentran desde el Principio 28 al 30, haciendo especial énfasis en el 29 puesto que enuncia de manera exacta el desarrollo que presenta la Ley 1448 de 2011.

1. Los desplazados internos que regresen a su hogar o a su lugar de residencia habitual o que se hayan reasentado en otra parte del país no serán objeto de discriminación alguna basada en su desplazamiento. Tendrán derecho a participar de manera plena e igualitaria en los asuntos públicos a todos los niveles y a disponer de acceso en condiciones de igualdad a los servicios públicos. 
2. Las autoridades competentes tienen la obligación y la responsabilidad de prestar asistencia a los desplazados internos que hayan regresado o se hayan reasentado en otra parte, para la recuperación, en la medida de lo posible, de las propiedades o posesiones que abandonaron o de las que fueron desposeídos cuando se desplazaron. Si esa recuperación es imposible, las autoridades competentes concederán a esas personas una indemnización adecuada u otra forma de reparación justa o les prestarán asistencia para que la obtengan (Principios Relativos al Regreso, el Reasentamiento y la Reintegración).

En la Resolución 60/147 aprobada por la Asamblea General de la onu el 16 de diciembre de 2005, sobre los "Principios y directrices básicos sobre el derecho de las víctimas de violaciones manifiestas de las normas internacionales de derechos humanos y de violaciones graves del derecho internacional humanitario a interponer recursos y obtener reparaciones", se hace una alusión a la obligación del Estado de asegurar que se respeten y se apliquen las normas de derechos humanos (DDHH) y derecho internacional humanitario (DIH).

La Corte Penal Internacional en su estatuto reitera en su jurisdicción internacional la protección de las personas en casos de delitos de lesa humanidad, crímenes de guerra y genocidio. El delito de desplazamiento forzado es conocido como desplazamiento ilegal, el cual se halla en el artículo 8, literal e, numeral VIII, puesto que se aplica a situaciones de conflicto no internacional, pero dentro del marco del derecho internacional.

En la Resolución 60/147 de la Asamblea General de las Naciones Unidas del 16 de diciembre de 2005, se hallan los principios y directrices para que las víctimas puedan interpo- 
ner recursos y obtener una reparación. Pero indagando a profundidad es necesario mencionar el numeral 19 que determina como parámetro "el restablecimiento de la libertad, el disfrute de los derechos humanos, la identidad, la vida familiar y la ciudadanía, el regreso a su lugar de residencia, la reintegración en su empleo y la devolución de sus bienes"(Principios y directrices básicos sobre el derecho de las víctimas de violaciones manifiestas de las normas internacionales de derechos humanos y de violaciones graves del derecho internacional humanitario a interponer recursos y obtener reparaciones, 2005, principio 19) y el derecho a la satisfacción de las víctimas (numeral 22) que ordena los Estados implementar:

a) Medidas eficaces para conseguir que no continúen las violaciones

b) La verificación de los hechos y la revelación pública y completa de la verdad, en la medida en que esa revelación no provoque más daños o amenace la seguridad y los intereses de la víctima, de sus familiares, de los testigos o de personas que han intervenido para ayudar a la víctima o impedir que se produzcan nuevas violaciones;

c) La búsqueda de las personas desaparecidas, de las identidades de los niños secuestrados y de los cadáveres de las personas asesinadas, y la ayuda para recuperarlos, identificarlos y volver a inhumarlos según el deseo explícito o presunto de la víctima o las prácticas culturales de su familia y comunidad;

d) Una declaración oficial o decisión judicial que restablezca la dignidad, la reputación y los derechos de la víctima y de las personas estrechamente vinculadas a ella;

e) Una disculpa pública que incluya el reconocimiento de los hechos y la aceptación de responsabilidades; 
f) La aplicación de sanciones judiciales o administrativas a los responsables de las violaciones;

g) Conmemoraciones y homenajes a las víctimas;

h) La inclusión de una exposición precisa de las violaciones ocurridas en la enseñanza de las normas internacionales de derechos humanos y del derecho internacional humanitario, así como en el material didáctico a todos los niveles"(Resolución 60/147).

\section{El derecho a la tierra}

La existencia de una garantía por parte del Estado a las personas de que la tierra no conlleva solo el derecho a la propiedad, en el caso de los campesinos, sino a más, genera una preocupación grande acerca de cuáles serían estos derechos conexos, pero la Corte Constitucional ha sido muy clara en este tema:

La protección internacional a los bienes patrimoniales, especialmente la tierra y el territorio se inspira en otros derechos humanos conexos, como son el derecho a la vida digna, el derecho a la alimentación adecuada, el derecho a una vivienda digna, el derecho a la tierra y a la seguridad de la tenencia de la misma. A pesar de no haber sido reconocido de manera explícita en la normatividad internacional [...] el derecho de "acceder a una alimentación adecuada, de manera sostenible, culturalmente aceptable y con respeto a la dignidad humana" y el derecho a trabajar o "el derecho de toda persona a tener la oportunidad de ganarse la vida" (Romero Correa, p. 6, 2009).

La vulneración de los anteriores derechos no solo se da dentro del marco nacional, sino en el contexto internacional con la violación de diferentes instrumentos internacionales y 
de derechos humanos, como el Pacto Internacional de Derechos Civiles y Políticos, el Pacto Internacional de Derechos Económicos, Sociales y Culturales, la Convención de los Derechos del Niño, la Convención sobre la Eliminación de toda Forma de Discriminación contra la Mujer, el artículo 3 Común de los Convenios de Ginebra y el Protocolo II Adicional a los Convenios de Ginebra.

Siguiendo el lineamiento anterior, se entiende que las personas víctimas (producto de los años de violencia dentro del Estado colombiano) tienen que ser protegidas, el mismo Estado debe velar por su protección y evitar que se presenten situaciones que generen desplazamiento forzado de colombianos. Sin embargo, y como señala la sentencia "por diversas razones, cuyo análisis desborda el marco de esta sentencia, el Estado debe procurar brindarles las condiciones necesarias para retomar a sus hogares o para iniciar una nueva vida en otros lugares"(Sentencia S.U-1150/00, p. 58, E. Cifuentes M.).

Sumado a la apreciación de la misma jurisprudencia, el Estado ha ignorado sus responsabilidades frente a las víctimas del conflicto, sus obligaciones y sobre todo la causa que ha producido el fenómeno del desplazamiento forzado, acreditando lo anterior la Corte cita los informes que han corroborado la información que se expone tales como el informe presentado al Congreso por la Consejería Presidencial para la Atención a la Población Desplazada en 1998, por la Consejería Presidencial para la Atención a la Población Desplazada y la Dirección General para los Derechos Humanos del Ministerio del Interior en 1999 y por la Red de Solidaridad Social en 2000.

Resaltando la importancia de las consideraciones de la Corte en este aspecto la misma cita: 
Evidentemente, la atención a más de un millón de personas desplazadas supone una inmensa tarea para el Estado colombiano. Pero, además, en el reto de desarrollarla a cabalidad se compromete la legitimidad del Estado: si el Estado — que de acuerdo con la teoría es la asociación que debe monopolizar el ejercicio de la fuerza - no fue capaz de impedir que sus asociados fueran expulsados de sus lugares de origen, tiene por lo menos que garantizarle a los ciento de miles de colombianos que han tenido que abandonar sus hogares y afrontar condiciones extremas de existencia la atención necesaria para poder reconstruir sus vidas.

Por último, se resalta la importancia de que a la Rama Ejecutiva del poder público le corresponde determinar los mecanismos prácticos mediante los cuales debe adelantarse la atención a los colombianos desplazados por la violencia. Para ello debe sujetarse a lo prescrito por la Rama Legislativa a través de la Ley 387 de 1997 "Por la cual se adoptan medidas para la prevención del desplazamiento forzados; la atención, protección, consolidación y esta estabilización socioeconómica de los desplazados internos por la violencia en la República de Colombia".

\section{Metodología de la investigación}

La investigación gira en torno a un tipo socio-jurídico en el cual juegan un papel importante los métodos cuantitativo y cualitativo, que se diferencian de manera radical en las técnicas que utilizan para resolver el problema previamente planteado de investigación. La aplicación de la Ley de Víctimas y Restitución de Tierras en el acompañamiento y asistencia dada a los campesinos es un campo humanista, en el cual influye la naturaleza de las personas que se estudian, sin olvidar ni 
dejar de lado el contexto del pasado y las situaciones en las que se halla cada individuo, es decir, se maneja el proceso de investigación desde la óptica cualitativa, que, como lo comentó Taylor, S.J.y Bodgan R. (1986), es una manera inductiva por medio de la cual se desarrollan problemas de trayectoria. La restitución de tierras desde el ámbito cualitativo es una investigación que produce datos descriptivos, desde las personas, el contexto y los grupos considerados como un todo.

\section{Enfoque de la investigación}

La investigación se encuentra en estado de ejecución, en el cual se ha desarrollado parcialmente el objetivo general de la misma obteniendo de tal una serie de interrogantes acerca de la Ley 1448 de 2011, ya que al revisar la implementación y aplicación de dicha norma es evidente que esta carece de un acompañamiento post-fallo por parte del Estado hacia los beneficiarios de esta norma.

Dentro del trabajo investigativo se ha avanzado con el primer objetivo específico que refiere al análisis de la Ley 1448 de 2011, herramienta que ha servido y servirá para continuar con la ejecución, ya que sirve como guía y orientación específicamente sobre lo que gira la investigación que es el análisis del acompañamiento post-fallo si lo hay, o una posible propuesta sobre el mismo.

Dentro del segundo objetivo específico planteado, se ha hecho un avance parcial, ya que hasta el momento se han elaborado las herramientas de recolección de la información, como son las entrevistas, encuestas y cuestionarios que serán de utilidad para determinar si existe o no el acompañamiento y la reparación integral posterior al agotamiento de la ruta y procedimiento para la restitución, respuesta que se obtendrá aplicando dichas herramientas en las visitas programadas a 
los municipios de Puerto Gaitán, San Martín y Cubarral en el departamento del Meta.

Investigación-acción-participación para el restablecimiento de los derechos humanos: La metodología elegida es el IAP que se desarrolla en una serie de etapas, con el fin de darle una respuesta a la implementación de la ley en los términos establecidos, respecto a la restitución.

\section{Socio jurídico}

La investigación socio-jurídica es el resultado de los temas y problemas que se investigan. La aplicación y restitución de tierras, visto desde el ámbito del acompañamiento técnico que pueda brindar el estado a las víctimas, sin duda alguna contiene derecho, su aplicación, su influencia y el resultado que pueda lograr. Con el transcurrir del tiempo, la investigación de tipo social desde el componente jurídico ha sido un aspecto importante en el estudio del derecho asociado con las ciencias sociales. Clásicos como Durkheim, Weber y Marx se han preguntado por la sociedad y por el derecho, importantes métodos que hoy nos brindan las herramientas para escudriñar en la Ley de 1448 de 2011, enfocando socialmente el acompañamiento y asistencia técnicos para el campesino por parte del departamento.

\section{Instrumentos de recolección de la información}

a. Identificar las acciones de la implementación de la Ley 1448 de 2011: Recolección y análisis de información. Documentos, derechos de petición, líneas jurisprudenciales, libros, extracto de foros, conferencias, capacitaciones y audiencias. 
b. Determinación de existencia de un acompañamiento y reparación integral: Aplicación de los instrumentos de recolección de información a los participantes de la investigación. Entrevistas, encuestas, cuestionarios y visita a los lugares.

c. Construcción de la estrategia: Cooperación interfacultades (Administración de Empresas Agropecuarias). Visitas a los lugares.

\section{Participantes}

Jueces de restitución de tierras (en el caso del departamento del Meta son dos), funcionarios administrativos y víctimas (identificadas previamente según los fallos emitidos).

\section{Reflexiones, avances y resultados parciales}

La posibilidad de dar un acompañamiento que sea integral como resalta la Ley 1448 de 2011, así como los instrumentos internacionales lo exigen, es una tarea del Estado en la cual este debe dar su máximo apoyo. El hecho de que una persona desplazada retorne a su lugar de origen no quiere decir que se haya completado el proceso de restitución, la formación integral de un plan de vida, en conjunto con las instituciones del Estado, es la garantía de que se cumpla lo propuesto por esta ley.

Hasta la fecha, en el departamento del Meta, en el proceso judicial existen cinco (5) fallos por parte de los Juzgados Civiles Especializados en Restitución de Tierras en Villavicencio y dos (2) sentencias en el Tribunal Superior de Bogotá, como ente de segunda instancia, de un total de 46 procesos en curso hasta el año 2013.

Como antecedente, en el año 2011 en Puerto López se recuperan las primeras tierras (38.000 hectáreas) y es conside- 
rada la primera restitución que se produjo en el departamento. En el año 2012 se presentan restituciones en otros lugares del Meta, tales como Servitá, por ejemplo. Dicha reclamación se "remonta a la época de la violencia desatada contra integrantes de la U.P. (Céspedes, 2014, p. 1).

Para el año 2013, en el mes de marzo se produce un fallo histórico pues se restituyen 8.408 hectáreas en el municipio de Tillavá, lo cual tiene como antecedente el destierro de los campesinos por parte de los paramilitares con el fin de erradicar a las Fuerzas Armadas Revolucionarias de Colombia (FARC). Por lo anterior en dicho fallo "se acumularon pretensiones y procesos, debido a la magnitud de la extensión del territorio"; el mes de julio de este mismo año se falla en Puerto Gaitán a favor de una familia que había sido desplazada doce años atrás.

Para el año 2014, por parte de la Unidad de Restitución de Tierras se avanza en procesos de micro-focalización, comunicación y notificación a solicitantes y poseedores de predios, en el municipio de Vistahermosa, siendo este el primer municipio que hace parte de la zona de consolidación en el cual se prestan las condiciones de seguridad para adelantar el respectivo proceso.

\section{Procesos de restitución de tierras en el Meta, Juzgado Primero Civil del Circuito Especializado en Restitución de Tierras}

En esta parte se hallan relacionados los procesos que cursan en dicho juzgado, los predios con respectiva identificación y lugar en que se encuentran. 
Tabla $1{ }^{3}$ Procesos de restitución de tierras, Villavicencio, Meta

\begin{tabular}{|c|c|c|}
\hline Total de procesos & Municipio & Departamento \\
\hline 46 & Villavicencio & Meta \\
\hline
\end{tabular}

Fuente: Juzgado 1 y 2 del Circuito de Restitución de Tierras de Villavicencio

\section{Procesos de restitución de tierras en el Meta,} Juzgado Segundo Civil del Circuito Especializado en Restitución de Tierras

En este capítulo se presenta los procesos destinados a este juzgado, con lo respecto a identificación y lugar en que se hayan.

Tabla 2. Procesos de restitución de tierras en el Meta, municipios

\begin{tabular}{|c|c|c|}
\hline Total de procesos & Municipio & Departamento \\
\hline 2 & Villavicencio & Meta \\
\hline 22 & Puerto Gaitán & Meta \\
\hline 1 & Acacías & Meta \\
\hline 1 & Restrepo & Meta \\
\hline 15 & El Dorado & Meta \\
\hline 1 & Orocué & Casanare \\
\hline 3 & Cabuyaro & Meta \\
\hline 2 & Puerto López & Meta \\
\hline 1 & Granada & Meta \\
\hline 1 & Cumaral & Meta \\
\hline 1 & El Castillo & Meta \\
\hline
\end{tabular}

Fuente: Juzgado 1 y 2 del Circuito de Restitución de Tierras de Villavicencio.

3 Céspedes, O.Y.(2014). Modelo de gestión para el mejoramiento y eficacia de los juzgados de restitución de tierras. Recopilación de Información. Trabajo de Investigación. Facultad de Derecho. Universidad Santo Tomás. Villavicencio. 


\section{Sentencias proferidas en materia de restitución de tierras en el Meta}

Tabla 3. Sentencias de restitución de tierras del departamento del Meta, por juzgados

\begin{tabular}{|c|l|}
\hline Total de Decisiones & \multicolumn{1}{c|}{ Juzgado } \\
\hline 5 & $\begin{array}{l}\text { Civil del Cto. Especializado en } \\
\text { Restitución de Tierras de Villavicencio }\end{array}$ \\
\hline 2 & Tribunal Superior de Bogotá \\
\hline
\end{tabular}

Fuente: Juzgado 1 y 2 del Circuito de Restitución de Tierras de Villavicencio.

\section{Discusión o conclusiones}

El legislador y el gobierno de turno, pretendiendo ser garantistas, impulsan la implementación de esta justicia transicional, que se queda un poco corta en la ejecución de sus postulados de justicia, verdad y reparación a las víctimas. En el tiempo que llevamos de nuestra investigación hemos notado que se genera una incertidumbre debido a que, siendo la Ley 1448 de 2011 un mecanismo transitorio, que supone resarcir los daños causados por el conflicto armado colombiano a todas las personas que hayan tenido que abandonar sus predios, en la vigencia de esta ley sean reparados de manera integral.

En el departamento del Meta, teniendo uno de los índices más altos de desplazamiento, abandono y despojo de la tierra al interior del país, existe tiene lugares donde las entidades administrativas aún no han podido hacer las micro-focalizaciones de los predios objeto de estudio para restituir. Esto nos deja ambigüedad respecto de cómo se va a garantizar sus derechos a los despojados y desterrados.

Ahora bien, partamos de la premisa de que se hicieron los trámites administrativos ante la Unidad de Tierras y luego el posible trámite judicial con los Jueces de Restitu- 
ción de Tierras, como ocurrió con la primera sentencia en el departamento del Meta, Radicado no 50001-31-21-201200064-00 en el predio Villa Diana. Teniendo en cuenta el ejemplo anterior, podemos dejar para discusión: ¿Qué pasará con estas personas que retornaron a sus tierras, gracias a la justicia transicional de la Ley 1448 del 2011? ¿Qué ocurriría con dicho acompañamiento post-fallo a estas personas que tienen una condición de vulnerabilidad, como sucedió en caso similar en la sentencia T-025 de 2004? ¿En dónde está el acompañamiento técnico una vez se ha restituido el predio? Pues bien, a estos planteamientos esperamos que durante la ejecución de la presente investigación se den respuesta y de igual forma aspiramos a proponer un mecanismo alterno que sirva de ruta para las instituciones del Estado que tienen que ejecutar la Ley 1448 del 2011.

\section{Referencias bibliográficas}

ACNur (2006). Base de datos legal. Recuperado de http://www. acnur.org/t3/fileadmin/scripts/doc.php?file=biblioteca/ $\mathrm{pdf} / 4711 \mathrm{~h}$

ACNuR (1998). Base de datos legal. Recuperado de http://www. acnur.org/t3/fileadmin/scripts/doc.php?file=biblioteca/ pdf/0022

ACNUR (2011). Derecho a la tierra y la restitución en la región caribe. Recuperado de http://www.acnur.org/t3/el-acnur/eventos/ derecho-a-la-tierra-y-la-restitucion-en-la-region-caribe/ Alfonso, F. S. (2006). Los invisibles y la lucha por el Derecho en Colombia. Bogotá: Universidad Santo Tomás.

Alfonso, F. S. (2009). Globalización de los Derechos Humanos. La "teoría de las generaciones”, ha muerto, ¡viva la teoría de las generaciones de Viena! IUSTA, 11-12. Recuperado de http://numanterioresviei.usta.edu.co/articulos/edi9/08-Al- 
fonso-Fjardo/GLOBALIZACION\%20DE\%20LOS\%20 DERECHOS\%20HUMANOS\%20-\%20ALFONSO\%20 FAJARDO.pdf

Alto Comisionado de las Naciones Unidas para los Derechos Humanos (2005). Principios y directrices básicos sobre el derecho de las victimas. Recuperado de http://www2.ohchr.org/ spanish/law/reparaciones.htm

Céspedes, O.Y.(2014). Modelo de gestión para el mejoramiento y eficacia de los juzgados de restitución de tierras. Trabajo de Investigación. Facultad de Derecho. Universidad Santo Tomás. Villavicencio.

Colombia. Corte Constitucional. Sentencia T-958 de 2001. M.P.: Eduardo Montealegre Lynett.

Colombia. Corte Constitucional. Sentencia T-025 de 2004. M.P.: Manuel José Cepeda Espinosa.

Colombia. Corte Constitucional. Sentencia C-370 de 2006. M.P.: Manuel José Cepeda Espinosa, Jaime Córdoba Triviño, Rodrigo Escobar Gil, Marco Gerardo Monroy Cabra, Álvaro Tafur Galvis, Clara Inés Vargas Hernández.

Colombia. Corte Constitucional. Auto 383 de 2010 M.P.: Luis Ernesto Vargas Silva.

Colombia. Departamento Nacional de Planeación (2014). Plan de financiación para la sostenibilidad de la Ley 1448 de 2011 (Documento CONPEs 3712). Bogotá: DNP.

Colombia. Departamento Nacional de Planeación (2014). Lineamiento, plan de ejecución de metas, presupuesto y mecanismo de seguimiento para el Plan Nacional de Atención y Reparación Integral a Victimas (Documento conPes 3726). Bogotá: DNP.

Colombia. Departamento Nacional de Planeación.(2014). Marco de gasto de mediano plazo 2013-2016 (Documento CONPES 3729). Bogotá D.C., Colombia: DNP. 
Colombia. Ministerio de Agricultura y Desarrollo Rural. Ley 1448 de 2011 (2011). Unidad de Restitución de Tierras. Recuperado de http://www.leydevictimas.gov.co/documents/10179/19132/completo.pdf

Colombia. Ministerio de Agricultura y Desarrollo Rural. (2012), Unidad de Restitución de Tierras. A toda marcha, avanza proceso de Restitución de Tierras en Colombia. Recuperado de http://www.restituciondetierras.gov. $\mathrm{co} /$ ?action $=$ article\&id $=62$

Colombia. Ministerio de Agricultura y Desarrollo Rural (2011). Decreto 4829 de 2011. Unidad de Restitución de Tierras. Recuperado de http://www.leydevictimas.gov.co/documents/10179/16672/dec482920122011.pdf/accf8277c915-400a-9734-9123e2a46312

Defensoría Delegada para los Derechos de las Poblaciones Desplazadas (2012). Seguimiento al cumplimiento a los mandatos de la Sentencia T-025 y sus autos, análisis del proceso de formulación y ajuste de los planes integrales únicos. Recuperado de http://www.defensoria.org.co/red/anexos/pdf/11/desplazados/inf_seg_025_agosto2012.pdf

Durán, D., Parra, J., Bohórquez, V., \& Centeno, A. (2007). Desplazamiento forzado en Colombia. Derechos, acceso a la justicia y reparaciones. PUBLICACIONES. Recuperado de: http://www. acnur.org/t3/fileadmin/scripts/doc.php?file=biblioteca/ pdf/6922

Hernández., E. F. (2010). Directriz para la atención diferencial de los niños, niñas y adolescentes víctimas de desplazamiento forzado en Colombia. Recuperado de http://www.acnur.org/t3/ fileadmin/scripts/doc.php?file=biblioteca/pdf $/ 7428$

MAPp-oeA (s.f.) (2012, 11 de septiembre). Colombia un camino para la paz. Recuperado de http://www.mapp-oea.net/ 
index.php?option=com_content\&view=article\&id=697\& Itemid $=92$

Plazas Vega, M. (2014, 22 de Mayo) El estado de cosas inconstitucional [en línea]. Ámbito Jurídico. Publicación mensual. Recuperado de http://www.ambitojuridico.com/ BancoConocimiento/N/noti-120907-06\%28el_estado_ de_cosas_inconstitucional\%29/noti-120907-06\%28el_estado_de_cosas_inconstitucional\%29.asp.

Registro Único de Víctimas (01 de mayo de 2014). Red Nacional de Información

Romero Correa,J.P.(2009). Despojo de la dignidad desplazamiento forzado y tierras. Tesis de Pregrado. Facultad de Derecho. Universidad Santo Tomás. Bucaramanga, Colombia. 
Este libro fue compuesto en caracteres Adobe Caslon Pro 11,2 puntos, impreso en propal de 70 gramos y encuadernado con método hot melt en enero de 2015, en Bogotá, D. C., Colombia 